\title{
Article \\ The Performance and Mechanism of a Mg-Al Double-Layer Oxide in Chloride ion Removal from an Aqueous Solution
}

\author{
Xueqin $\mathrm{Xu}{ }^{1} \oplus$, Peng $\mathrm{Li}^{2}$, Shichong Yang ${ }^{2}$, Tong Zhang ${ }^{2}$, Xiangke Han ${ }^{2}$, Guoli Zhou ${ }^{2, *}$, Yijun Cao ${ }^{2, *}$ \\ and Daoguang Teng ${ }^{2}$ \\ 1 Henan Province Industrial Technology Research Institution of Resources and Materials, \\ Zhengzhou University, Zhengzhou 450001, China; xxq18838180617@163.com \\ 2 School of Chemical Engineering, Zhengzhou University, Zhengzhou 450001, China; \\ zdhglipeng@zzu.edu.cn (P.L.); yscofzzu@163.com (S.Y.); yoygat@163.com (T.Z.); xiangkehan@163.com (X.H.); \\ teng_daoguang@zzu.edu.cn (D.T.) \\ * Correspondence: zglcumt@126.com (G.Z.); yijuncao@126.com (Y.C.); \\ Tel.: +86-371-6778-1081 (G.Z.); +86-371-6773-9808 (Y.C.)
}

Citation: Xu, X.; Li, P.; Yang, S.; Zhang, T.; Han, X.; Zhou, G.; Cao, Y.; Teng, D. The Performance and Mechanism of a Mg-Al Double-Layer Oxide in Chloride ion Removal from an Aqueous Solution. Nanomaterials 2022, 12, 846. https://doi.org/ $10.3390 /$ nano12050846

Academic Editor: Giorgio Vilardi

Received: 14 January 2022

Accepted: 28 February 2022

Published: 2 March 2022

Publisher's Note: MDPI stays neutral with regard to jurisdictional claims in published maps and institutional affiliations.

Copyright: (C) 2022 by the authors. Licensee MDPI, Basel, Switzerland. This article is an open access article distributed under the terms and conditions of the Creative Commons Attribution (CC BY) license (https:// creativecommons.org/licenses/by/ $4.0 /)$.

\begin{abstract}
The increasing threat of chloride ions $\left(\mathrm{Cl}^{-}\right)$has led researchers to explore efficient removal technologies. Sewage treatment with a double-layer hydroxide/oxide (LDH/LDO) is receiving increasing attention. In this work, Mg-Al LDO adsorbents were produced by the calcination of the Mg-Al LDH precursor, which was constituted by improved coprecipitation. The influence of calcination temperature, calcination time, adsorbent dosage, $\mathrm{Cl}^{-}$initial concentration, contact time, and adsorption temperature on $\mathrm{Cl}^{-}$elimination was investigated systematically. The experimental results showed that a better porous structure endowed the $\mathrm{Mg}-\mathrm{Al} \mathrm{LDO}$ with outstanding adsorption properties for $\mathrm{Cl}^{-}$. The adsorption process was well matched to the pseudo-second-order kinetics model and the Freundlich model. Under optimal conditions, more than $97 \%$ of the $\mathrm{Cl}^{-}$could be eliminated. Moreover, the removal efficiency was greater than $90 \%$ even after 11 adsorptiondesorption cycles. It was found that the electrostatic interaction between $\mathrm{Cl}^{-}$and the positively charged $\mathrm{Mg}-\mathrm{Al} \mathrm{LDO}$ laminate, coupled with the reconstruction of the layer structure, was what dominated the $\mathrm{Cl}^{-}$removal process.
\end{abstract}

Keywords: $\mathrm{Mg}-\mathrm{Al} \mathrm{LDO} ; \mathrm{Cl}^{-}$removal; adsorption kinetics; electrostatic adsorption; reusability

\section{Introduction}

Large quantities of chloride wastewater are generated by the metallurgical and chemical industries [1,2]. $\mathrm{Cl}^{-}$concentration in this wastewater is much greater than $2000 \mathrm{mg} \mathrm{L}^{-1}$, even up to $10,000 \mathrm{mg} \mathrm{L}^{-1}$ [3]. It is the high fluidity, activity, and stability of $\mathrm{Cl}^{-}$that make it difficult to remove [4]. $\mathrm{Cl}^{-}$can destroy the passive film to corrode the pipelines of the water circulation system when it has frequent exposure to metal [3,5]. Furthermore, most of the scale and corrosion inhibitors cannot really inhibit $\mathrm{Cl}^{-}$corrosion during the process of production. At present, being dependent on the first-level water discharge requirements of the salt chemical industry, the $\mathrm{Cl}^{-}$content must be kept below $300 \mathrm{mg} \mathrm{L}^{-1}$. Therefore, it is necessary and important to find a green treatment technology for $\mathrm{Cl}^{-}$in the wastewater.

Great effort has been made toward alleviating the dire situation of $\mathrm{Cl}^{-}$concentration in wastewater, including precipitation [3,4,6], evaporation and concentration [7], oxidationreduction [8,9], and ion exchange [10]. However, it is worth noting that the methods described above are hard to practically apply to industrial wastewater due to prohibitive operating costs, inefficiency, limitations of treatment concentration, and a lack of suitable oxidants. By contrast, adsorption is gaining attention due to the fact that it does not harm the environment, has a straightforward process, is low in cost, and is highly efficient [11,12]. Hydrotalcite-like compounds, inorganic functional materials with layered structures, are considered to be highly promising, highly efficient adsorbents due to several factors. Their 
theoretical specific surface areas are large, the hydrophilicity is strong, the interlayer charge density and reactivity is high, the economic consumption is low, and efficiency is satisfactory [11].

LDHs, also known as hydrotalcites, are a class of two-dimensional anionic intercalation materials with a bimetallic hydroxide laminate and exchangeable intercalation anions [13]. They are widely applied in adsorption, catalysis [14-16], energy storage [17,18], biology [19], medicine release [20-22], heavy metal ions [23,24], and functional materials [25-28]. Their general formula can be given by $\left(\mathrm{M}^{2+}{ }_{1-\mathrm{x}} \mathrm{M}^{3+}{ }_{\mathrm{x}}(\mathrm{OH})_{2}\right)\left(\mathrm{A}^{\mathrm{n}-}\right)_{\mathrm{x} / \mathrm{n}} \cdot \mathrm{mH}_{2} \mathrm{O}$ [29]. Their laminate elements are characteristically available in variable types and various proportions; changeable interlayer anions and controllable sizes also bring more possibility in terms of application of the materials [30,31]. Anions such as $\mathrm{NO}_{3}{ }^{-}$can be exchanged with $\mathrm{CO}_{3}{ }^{2-}$, $\mathrm{SO}_{4}{ }^{2-}$, and $\mathrm{Cl}^{-}$. In addition, $\mathrm{LDHs}$ that are calcined can undergo structural transformation and convert into metal oxides (LDOs) with thermal and chemical stability. When LDHs are calcined, most of the interlayer anions are eliminated and then can be incorporated during rehydration to reconstruct the LDOs into their original layered structure, which is called "the structure memory effect." It is possible to recover the layered structure of mixed oxides when they come in contact with water [32]. The exchange between negative anions in the aqueous solution and the remaining anions in the interlayer can further improve the removal efficiency of the target ions. LDO is becoming a popularly used adsorbent in wastewater treatment $[33,34]$.

In recent years, more research has been conducted on LDH. Most of them were focused on the impact of the component and structure, preparation and modification methods of hydrotalcite, and the application of functionalized LDH [35-40]. However, there are limited studies that focus on the absorption of $\mathrm{Cl}^{-}$by LDO [41-44]. Therefore, it is crucial to provide current research and update previous findings on the removal of $\mathrm{Cl}^{-}$using doublelayer hydroxide/oxide materials as adsorbents.

Within this paper, an improved coprecipitation method [45] was adopted in order to fabricate the $\mathrm{Mg}-\mathrm{Al} \mathrm{LDH}$ precursor and then the adsorbent was produced by the calcination of that precursor. The structure of this adsorbent was adapted by changing the $\mathrm{M}^{2+} / \mathrm{M}^{3+}$ and the calcination temperature and time. The properties of the materials were studied by the systematic characterization and batch experiments. The influence of different calcination temperatures, calcination time, adsorbent doses, $\mathrm{Cl}^{-}$initial concentration, contact time, and adsorption temperatures on $\mathrm{Cl}^{-}$removal efficiency was explored. These findings were used to clarify the adsorption law and the adsorption mechanism of $\mathrm{Mg}-\mathrm{Al} \mathrm{LDO}$ on $\mathrm{Cl}^{-}$in water. In addition, stability and reusability of LDO materials were studied.

\section{Experiment}

\subsection{Reagents}

Sodium hydroxide $(\mathrm{NaOH})$ was purchased from Sinopharm Chemical Reagent Co., Ltd. (Shanghai, China). Aluminum nitrate was purchased from Shanghai Macklin Biochemical Co., Ltd., and magnesium nitrate was obtained from Tianjin Kermel Reagent Technologies Co., Ltd., Tianjin, China. All of these chemicals were of analytical purity, and they were used without further purification during the entire experiment. Magnesium nitrate $\left(\mathrm{Mg}\left(\mathrm{NO}_{3}\right)_{2} \cdot 6 \mathrm{H}_{2} \mathrm{O}\right)$, aluminum nitrate $\left(\mathrm{Al}\left(\mathrm{NO}_{3}\right)_{3} \cdot 9 \mathrm{H}_{2} \mathrm{O}\right)$, and sodium hydrate $(\mathrm{NaOH})$ were used to prepare the $\mathrm{LDH}$ precursor. Sodium chloride $(\mathrm{NaCl})$ was used to prepare the standard solution of chloride. Deionized water was used throughout the experiment.

\subsection{Preparation of the Adsorbents}

The adsorbents used were produced by the calcination of the Mg-Al LDH precursor, which was fabricated by improved coprecipitation implemented at room temperature [45]. The calcination temperature and the calcination time were optimized during the process (as shown in Figures S1 and S2).

When the molar ratio of $\mathrm{M}^{3+} /\left(\mathrm{M}^{2+}+\mathrm{M}^{3+}\right)$ was between 0.2 and 0.4 [46], a structured LDH could be acquired. In addition, considering the standardization and rationality of 
the experimental design, the $\mathrm{M}^{2+}: \mathrm{M}^{3+}$ molar ratios of 2:1, 3:1, 4:1, 5:1, and 6:1 were chosen to fabricate the precursor. Based on the molar ratio, different masses of $\mathrm{Mg}\left(\mathrm{NO}_{3}\right)_{2} \cdot 6 \mathrm{H}_{2} \mathrm{O}$ and $\mathrm{Al}\left(\mathrm{NO}_{3}\right)_{3} \cdot 9 \mathrm{H}_{2} \mathrm{O}$ were mixed together to prepare $250 \mathrm{~mL}$ of a mixed metal nitrate solution (A). The salt solution (A) and an alkaline solution (B) $(\mathrm{NaOH})=3 \mathrm{M}(250 \mathrm{~mL})$ were rapidly mixed, and a white slurry was formed synchronously. The solution obtained was kept aging for $18 \mathrm{~h}$ at room temperature, and the supernatant was divided by filtering. The thick slurry was washed using deionized water until the filtrate was close to neutral, and then they were dried for $10 \mathrm{~h}$ in the oven at $70{ }^{\circ} \mathrm{C}$. White $\mathrm{Mg}$-Al LDH precursors were created, and the precursor particles below $74 \mu \mathrm{m}$ in size were selected by crushing and screening. The elemental ratios were confirmed by EDS analysis (as shown in Figure S3 and Table S1). The Mg-Al LDO adsorbent powders were produced by the calcination of the precursors in a muffle furnace with an accompanying heating rate of $10{ }^{\circ} \mathrm{C} \mathrm{min}{ }^{-1}$. When the furnace finally got to the target of $480^{\circ} \mathrm{C}$, the sample was kept inside for $3 \mathrm{~h}$ (as shown in Figure S4).

\subsection{Analysis Methods}

The X-ray diffraction (XRD) patterns of samples were collected using $\mathrm{Cu} \mathrm{K} \alpha$ radiation at an ambient temperature between $5^{\circ}$ and $80^{\circ}(2 \theta)$ with $0.013^{\circ}$ step sizes (PANalytical, Malvern, Netherlands, Empyrean). X'Pert High Score Plus was used for analyzing the XRD pattern and calculating the d-value. Fourier-transform infrared spectroscopy (FT-IR) was performed using a Nicolet iS10 FT-IR spectrometer (Thermo Fisher Scientific, Waltham, MA, USA) within 500-4000 $\mathrm{cm}^{-1}$. The changes in the surface morphology of the samples were observed using scanning electron microscopy (SEM, Zeiss, Jena, Germany, Sigma 300). A Brunner-Emmett-Teller (BET) analysis (BELSORP Max II, MicrotracBEL, Osaka, Japan) was conducted to investigate the pore structure parameters of the materials before and after the $\mathrm{Cl}^{-}$removal experiments. The samples were pre-treated at $105^{\circ} \mathrm{C}$ for $8 \mathrm{~h}$ under vacuum and were measured at a temperature of $-196.15^{\circ} \mathrm{C}(77 \mathrm{~K})$. Zeta potential parameters of materials were measured using a Malvern Zetasizer nano series (Malvern Panalytical Ltd., Malvern, UK). Lastly, the thermostability of the materials was measured using a thermogravimetric analyzer (TGA) (Netzsch, STA449 F5, Selb, Germany).

\subsection{Adsorption Experiments}

Batch methods were employed to understand the effect of the $\mathrm{Mg} / \mathrm{Al}$ molar ratio, calcination temperatures, the calcination time, adsorbent doses, the $\mathrm{Cl}^{-}$initial concentration, the contact time, and the adsorption temperature.

The experiment was launched by transferring $25 \mathrm{~mL}$ of the $\mathrm{NaCl}$ solution into $100 \mathrm{~mL}$ Erlenmeyer flasks using a pipette. A certain amount of the adsorbent was put into the flasks at $293 \mathrm{~K}$. The mixed solution was stirred magnetically at 300-320 r/min for $2 \mathrm{~h}$. The $\mathrm{Cl}^{-}$concentration of the supernatant was detected using an ion chromatograph (Thermo Fisher Scientific). The removal rate calculation formula is as follows [25]:

$$
Y=\frac{C_{0}-C_{e}}{C_{0}} \times 100 \%
$$

where $Y(\%)$ is the $\mathrm{Cl}^{-}$removal rate and $C_{0}\left(\mathrm{mg} \mathrm{L}^{-1}\right)$ and $C_{e}\left(\mathrm{mg} \mathrm{L}^{-1}\right)$ are the initial and equilibrium concentrations of $\mathrm{Cl}^{-}$, respectively.

In the case of pollution, plastic wrap was used during the experiments. The adsorption kinetics were carried out in a specific time, and the adsorption isotherms were plotted at 293 K. All adsorption experiments were repeated, and the average data were used to assess the adsorption performance.

\section{Results and Discussion}

\subsection{Effect of $\mathrm{M}^{2+} / \mathrm{M}^{3+}$ on the $\mathrm{Mg}-\mathrm{Al} \mathrm{LDO}$ Adsorbent}

The structures of the precursor were studied, and the adsorption properties of the $\mathrm{Mg}$-Al LDO adsorbent with different $\mathrm{M}^{2+} / \mathrm{M}^{3+}$ molar ratios were studied. When the 
molar ratio of $\mathrm{M}^{3+} /\left(\mathrm{M}^{2+}+\mathrm{M}^{3+}\right)$ was between 0.2 and 0.4 [46], a structured LDH could be acquired.

To research the influence of different $\mathrm{Mg} / \mathrm{Al}$ molar ratios on $\mathrm{Cl}^{-}$removal, firstly, the composition of the adsorbents was optimized by modifying this ratio. As shown in Figure $1 \mathrm{c}, \mathrm{Cl}^{-}$removal efficiency strongly correlates with the rising $\mathrm{Mg}^{2+}$ mole ratio of $\mathrm{Mg}-\mathrm{Al} \mathrm{LDO} ; n\left(\mathrm{Mg}^{2+}\right): n\left(\mathrm{Al}^{3+}\right)$ impacts removal efficiency in a significant way. As there was a rise in the molar ratio, the removal efficiency of $\mathrm{Cl}^{-}$firstly decreased but then increased. When $n\left(\mathrm{Mg}^{2+}\right): n\left(\mathrm{Al}^{3+}\right)$ was $6: 1$, the $\mathrm{Cl}^{-}$removal was highly competent, at $93.06 \%$. In Figure $1 \mathrm{a}$, the additional crystalline phase that is present in the $\mathrm{Mg}: \mathrm{Al}=5: 1$ and $\mathrm{Mg}: \mathrm{Al}=6: 1$ sample was allocated to $\mathrm{Mg}(\mathrm{OH})_{2}$ [47], whose reflection peaks were at $18.6^{\circ}, 38.0^{\circ}, 50.9^{\circ}$, and $58.7^{\circ}$. Accompanying the rise in the ion ratio, the layer spacing of the synthesized materials gradually changed from 0.763 to $0.793 \mathrm{~nm}$ and finally appeared to become stable. With the increase in the divalent metal cation content, the charge density of the laminate decreases. The decrease in the stability and the increase in the spacing of the interlayer anions caused by the decrease in the charge density of the laminates are the reasons for the rise in the layer spacing. Combined with the results of material characterization and analysis, the calculation method of layer spacing $d_{h k l}=\frac{a}{\sqrt{\frac{4}{3}\left(h^{2}+k^{2}+h k+l^{2} \frac{a^{2}}{c^{2}}\right.}}$ was obtained.

The rise in the removal efficiency was imputed to the increase in the relative fraction of the $\mathrm{MgO}$ accompanying the gain in the $\mathrm{Mg}^{2+}: \mathrm{Al}^{3+}$ molar ratio. When the $\mathrm{LDO}$ was placed into the $\mathrm{NaCl}$ solution, the $\mathrm{MgO}$ transformed back into the $\mathrm{Mg}(\mathrm{OH})_{2}$ phase and adsorbed the other ions to restore the original layered structure [30]. Taking account of the high efficiency and stability of data, the mole ratio of $\mathrm{Mg}^{2+}: \mathrm{Al}^{3+}=6: 1$ was selected to assess the mechanism of $\mathrm{Cl}^{-}$incorporation by the adsorbent.
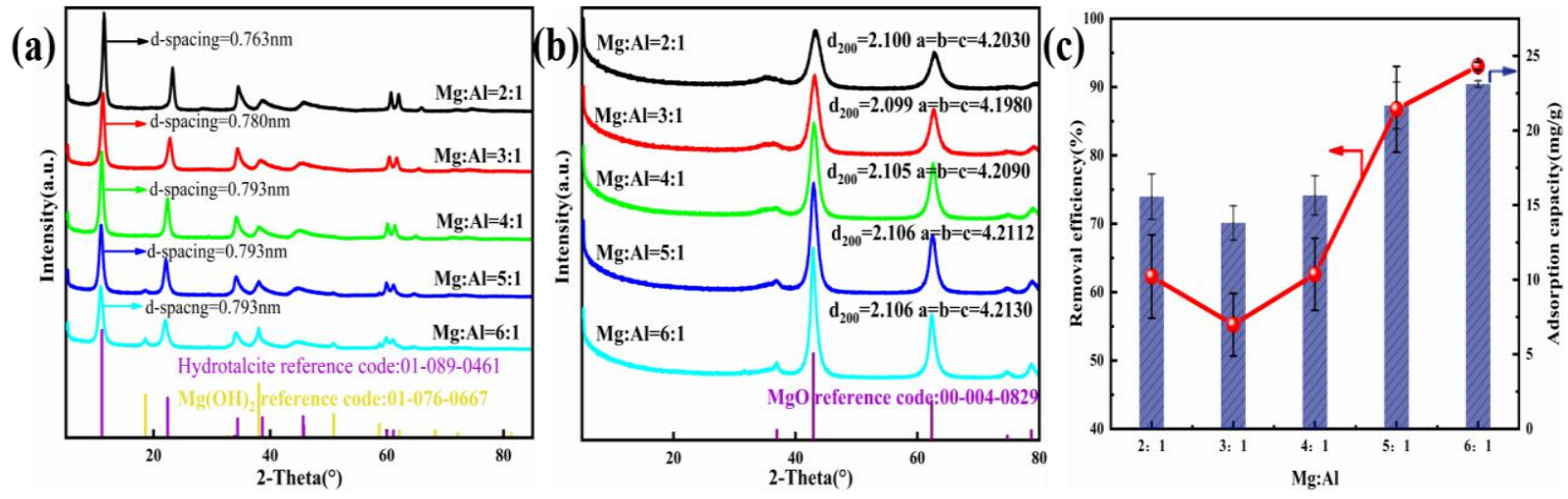

Figure 1. (a) XRD pattern of the precursor. (b) Diffractograms of the LDO materials. (c) Adsorption properties of the adsorbent with different $\mathrm{M}^{2+} / \mathrm{M}^{3+}$.

XRD patterns and parameters of the LDH precursor are presented in Figure 1a and Table 1. Reflection peaks typically seen in double-layer hydroxide structures were noted in all samples. Reflections peaks at $11.6^{\circ}, 23.4^{\circ}, 60.7^{\circ}$, and $62.1^{\circ}$ could be indexed to the crystal faces (003), (006), (110), and (113), which are typical to LDH structures [48,49]. In addition, the peaks at $34.9^{\circ}, 39.4^{\circ}$, and $46.9^{\circ}$ corresponded to asymmetric planes at (012), (015), and (018), which reveals the characteristics of hydrotalcite-like compounds [50].

Table 1. Layer spacing of the crystal plane under different ratios of materials.

\begin{tabular}{cccccc}
\hline & Mg:Al = 2:1 & Mg:Al = 3:1 & Mg:Al = 4:1 & Mg:Al = 5:1 & Mg:Al = 6:1 \\
\hline d-spacing/nm & 0.763 & 0.780 & 0.793 & 0.793 & 0.793 \\
$2 \theta /^{\circ}$ & 11.593 & 11.335 & 11.152 & 11.152 & 11.152 \\
a & 0.307 & 0.305 & 0.308 & 0.308 & 0.308 \\
c & 2.295 & 2.340 & 2.378 & 2.378 & 2.378 \\
\hline
\end{tabular}


Diffractograms and parameters of LDO are presented in Figure 1b. Reflection peaks typically seen in magnesium oxide were noted in all adsorbents. In addition, accompany the increase in the ion molar ratio, the diffraction peak of magnesium oxide becomes stronger and narrower, which indicates the increase in the metal oxide content. This is also in line with our conclusion that the relative fraction of $\mathrm{MgO}$ was responsible for the rise in removal efficiency.

The $\mathrm{N}_{2}$ adsorption-desorption isotherms and parameters of the LDO materials with different ion molar ratios are presented in Figure 2 and Table 2. Narrow adsorptiondesorption hysteresis loops and type IV isotherm were observed in all samples [51,52]. Accompany the rise in the $\mathrm{Mg} / \mathrm{Al}$ molar ratio, the average pore diameter increased and reached $23.958 \mathrm{~nm}$ when the $\mathrm{Mg} / \mathrm{Al}=6: 1$. The larger average pore diameter can expose more active sites and provide favorable conditions for $\mathrm{Cl}^{-}$adsorption.

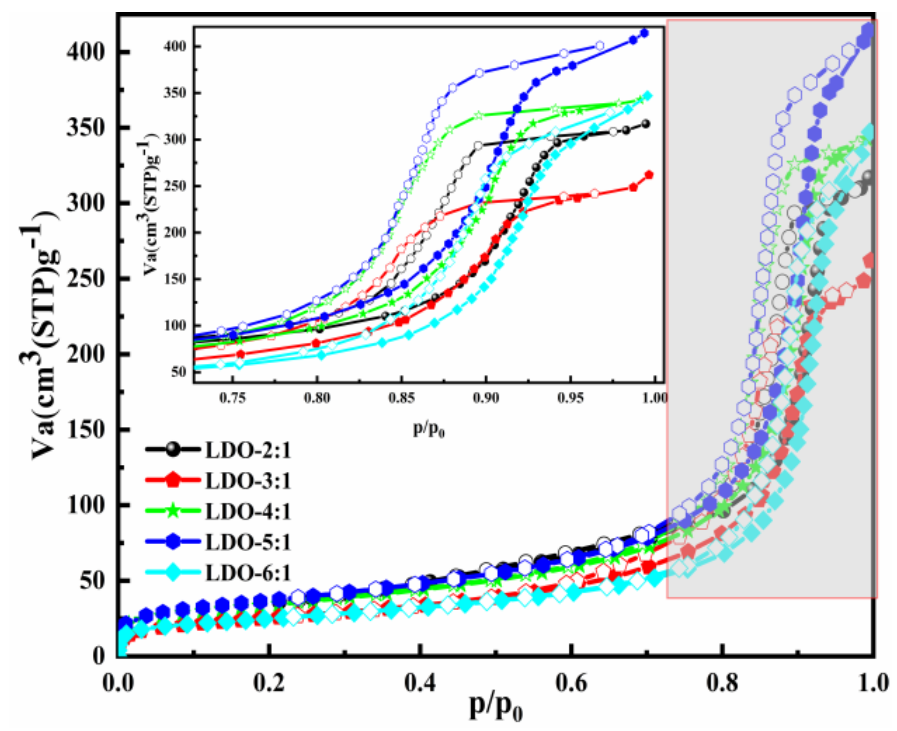

Figure 2. The textural properties of the adsorbents with different ion molar ratios.

Table 2. Specific surface area, total pore volume, and average pore diameter of the LDO with different ion molar ratios.

\begin{tabular}{|c|c|c|c|}
\hline Materials & $\begin{array}{l}\text { Specific Surface } \\
\text { Area }\left(\mathrm{m}^{2} \mathrm{~g}^{-1}\right)\end{array}$ & $\begin{array}{l}\text { Total Pore Volume } \\
\qquad\left(\mathrm{cm}^{3} \mathrm{~g}^{-1}\right)\end{array}$ & $\begin{array}{c}\text { Average Pore Diameter } \\
(\mathrm{nm})\end{array}$ \\
\hline LDO-2:1 & 128.311 & 0.49 & 15.153 \\
\hline LDO-3:1 & 91.889 & 0.39 & 17.015 \\
\hline LDO-4:1 & 113.943 & 0.53 & 17.494 \\
\hline LDO-5:1 & 130.425 & 0.63 & 19.471 \\
\hline LDO-6:1 & 121.074 & 0.52 & 24.081 \\
\hline
\end{tabular}

\subsection{Adsorption Properties}

\subsubsection{Effect of the Adsorbent Dose}

Figure 3 shows the influence of the variation in the adsorbent dose in $\mathrm{Cl}^{-}$removal. There is enhanced $\mathrm{Cl}^{-}$removal efficiency as the $\mathrm{Mg}-\mathrm{Al} \mathrm{LDO}$ concentration increases. The reason for this may be the increase in accessible active sites for adsorption [50]. When the Mg-Al LDO (Mg:Al = 6:1) dose was $2 \mathrm{~g}$, the removal efficiency of this material reached $97.90 \%$ and the adsorption capacity was $24.88 \mathrm{mg} / \mathrm{g}$. This may be linked to the pore diameter, which was obviously larger after calcination (Table S3). The increase in the removal efficiency, which positively shifted from $93.12 \%$ to $97.90 \%$, may be explained by reference to the rise in active sites of adsorption due to the Mg-Al LDO dose. That is, with the increase in the material dose, the active sites exposed were sufficient for the adsorption of $\mathrm{Cl}^{-}$. Thus, the removal efficiency of $\mathrm{Cl}^{-}$increased during the experiment. 
$\mathrm{Cl}^{-}$removal efficiency was positively changed by $0.87 \%$ (from $97.90 \%$ to $98.77 \%$ ) when there was a more significant increase, of $3 \mathrm{~g}$, in the $\mathrm{Mg}$-Al LDO dose (from 2 to $5 \mathrm{~g}$ ). This implies that the effect of the dose on the removal of $\mathrm{Cl}^{-}$is insignificant when the amount of adsorbent exceeds $2 \mathrm{~g}$. In addition, accompanying the increase in the material dose from 1 to $5 \mathrm{~g}$, the adsorption capacity negatively changed by $37.16 \mathrm{mg} / \mathrm{g}$ (from 47.22 to $10.06 \mathrm{mg} / \mathrm{g})$. When the amount of material increases, the aggregation of the material and competition for $\mathrm{Cl}^{-}$may occur, resulting in a scenario in which the active sites cannot be fully used. Under the condition that the amount of $\mathrm{Cl}^{-}$is consistent, the adsorption capacity decreases. Taking into consideration the $\mathrm{Cl}^{-}$removal efficiency, the impact on adsorption capacity, and economic benefits, we could consider $2 \mathrm{~g}$ as the optimal dose to be employed in further research.

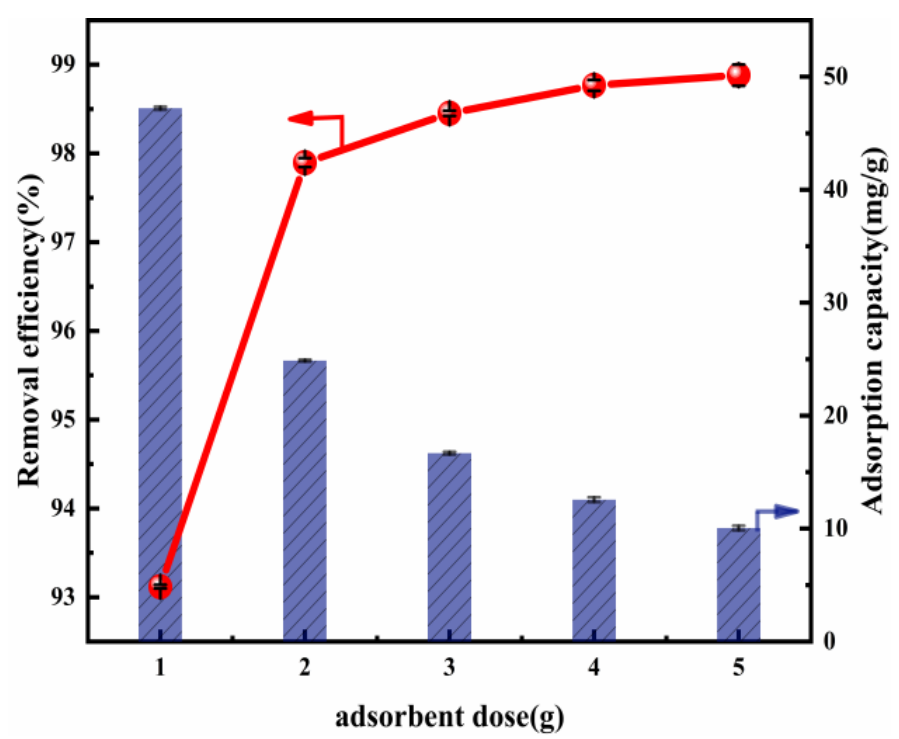

Figure 3. $\mathrm{Cl}^{-}$removal efficiency and adsorption capacity as a function of the adsorbent dosage (ion ratio $\mathrm{Mg}: \mathrm{Al}=6: 1 ; \mathrm{Cl}^{-}$initial concentration: $2000 \mathrm{mg} \mathrm{L}^{-1}$; adsorption temperature: $293 \mathrm{~K}$; contact time: $13 \mathrm{~h})$.

\subsubsection{Effect of the Initial $\mathrm{Cl}^{-}$Concentration}

The initial concentration of $\mathrm{Cl}^{-}$significantly affects its removal efficiency. It is assumed that a high concentration of $\mathrm{Cl}^{-}$is competitive at the adsorption sites [53]. The initial concentration of $\mathrm{Cl}^{-}$, which was within the range of $500-4250 \mathrm{mg} \mathrm{L}^{-1}$, was used in the adsorption experiment. The influence of the initial concentration of $\mathrm{Cl}^{-}$upon its removal efficiency and adsorption capacity is presented in Figure 4. The adsorption capacity increased rapidly from 5.92 to $40.50 \mathrm{mg} / \mathrm{g}$, accompanying the rise in the initial concentration of $\mathrm{Cl}^{-}$. However, the adsorption efficiency then decreased. An explanation for this result may be that there were abundant active sites to be used at a lower $\mathrm{Cl}^{-}$concentration, while there was increased competition between $\mathrm{Cl}^{-}$at a higher $\mathrm{Cl}^{-}$concentration. The experiments above were carried out with a fixed adsorption dose $(2 \mathrm{~g})$ and ion ratio (Mg:Al = 6:1). If the amount of adsorbent was increased, more active sites could be provided and the removal efficiency would increase, as can be seen in Figure 3. These results show that $\mathrm{Cl}^{-}$removal could be made much more efficient. 


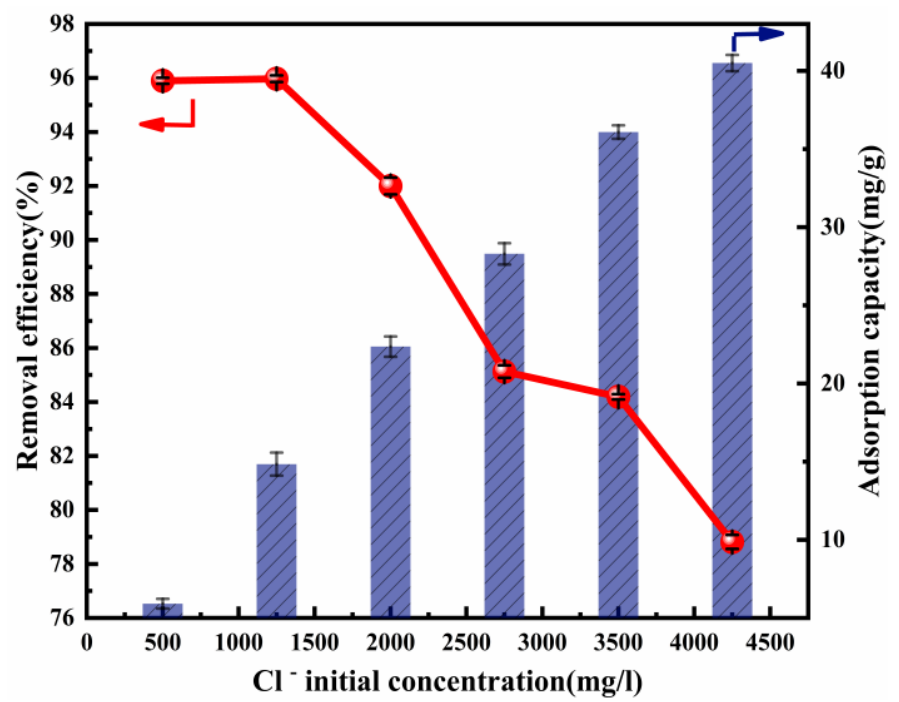

Figure 4. $\mathrm{Cl}^{-}$removal efficiency and adsorption capacity as a function of the $\mathrm{Cl}^{-}$initial concentration (ion ratio $\mathrm{Mg}: \mathrm{Al}$ = 6:1; adsorbent dose: 2 g; adsorption temperature: $293 \mathrm{~K}$; contact time: $13 \mathrm{~h}$ ).

\subsubsection{Effect of the Contact Time}

Contact time is a key parameter by which to assess the performance of the adsorbent, especially in the progress of actual wastewater treatment, where economic benefits are concerned [25]. The influence when the contact time is raised from 1 to $20 \mathrm{~h}$ at $293 \mathrm{~K}$ is shown in Figure 5. It can be pointed out that there was a significant impact upon $\mathrm{Cl}^{-}$ removal. $\mathrm{Cl}^{-}$removal efficiency increased rapidly from $19.35 \%$ to $96.96 \%$ as the contact time was increased from 1 to $13 \mathrm{~h}$. This increased especially sharply during the initial $8 \mathrm{~h}$ and gradually became almost constant, ranging between about $96.96 \%$ and $98.08 \%$, after $13 \mathrm{~h}$. Taking into account the $\mathrm{Cl}^{-}$removal efficiency and economic benefits, the optimal contact time chosen was $13 \mathrm{~h}$, which was also set in the other adsorption experiments.

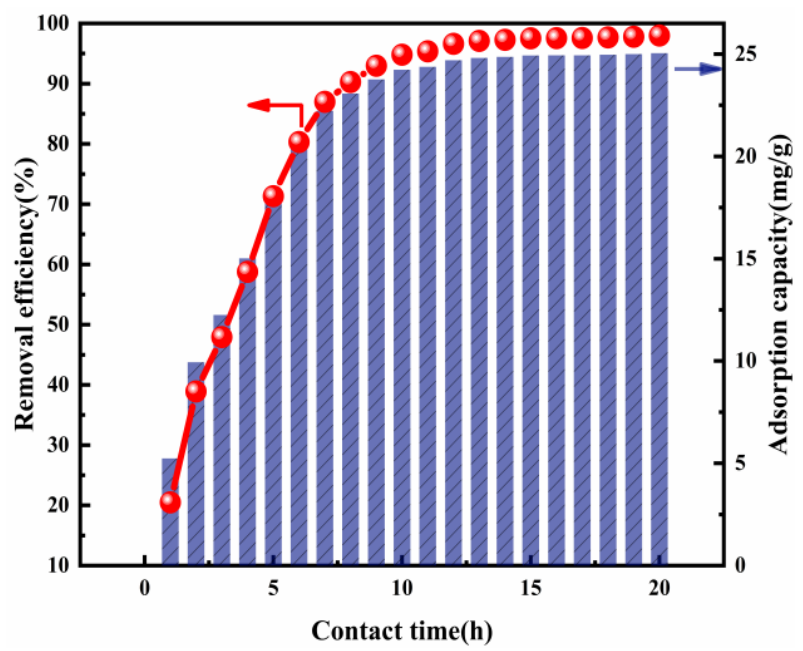

Figure 5. $\mathrm{Cl}^{-}$removal efficiency and adsorption capacity as a function of contact time (ion ratio $\mathrm{Mg}: \mathrm{Al}=6: 1 ; \mathrm{Cl}^{-}$initial concentration: $2000 \mathrm{mg} \mathrm{L}^{-1}$; adsorbent dose: 2 g; adsorption temperature: $293 \mathrm{~K})$.

\subsubsection{Effect of the Adsorption Temperature}

The temperature of the solution is an important factor in the adsorption process. Figure 6 shows the impact of the adsorption temperature on $\mathrm{Cl}^{-}$removal. The experimental results were achieved within the temperature range of $293-333 \mathrm{~K}$ in the contact time of $13 \mathrm{~h}$ and an ion ratio $\mathrm{Mg}: \mathrm{Al}$ of 6:1. As the adsorption temperature was increased from 293 
to $333 \mathrm{~K}$, the $\mathrm{Cl}^{-}$removal efficiency raised sharply. It rose particularly sharply between the contact time of $10 \mathrm{~min}$ and $2 \mathrm{~h}$. When the adsorption temperatures were 293, 313, and $333 \mathrm{~K}$, the $\mathrm{Cl}^{-}$removal efficiency was $95.78 \%, 97.39 \%$, and $97.93 \%$, respectively. The $\mathrm{Cl}^{-}$ adsorption equilibrium time was greatly shortened to accompany the rise in the adsorption temperature. The adsorption process reached equilibrium within $1 \mathrm{~h}$, when the adsorption temperature was $333 \mathrm{~K}$. These results indicate that increasing the temperature can speed up the adsorption process.

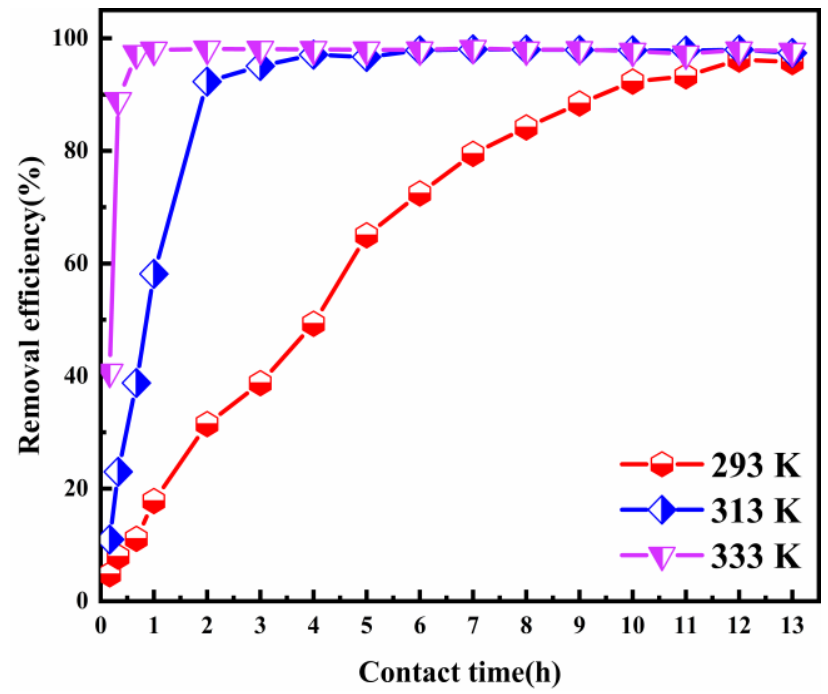

Figure 6. $\mathrm{Cl}^{-}$removal efficiency as a function of the adsorbent dose (ion ratio $\mathrm{Mg}: \mathrm{Al}=6: 1 ; \mathrm{Cl}^{-}$initial concentration: $2000 \mathrm{mg} \mathrm{L}^{-1}$; adsorbent dosage: $2 \mathrm{~g}$; contact time: $13 \mathrm{~h}$ ).

\subsection{Adsorption Kinetics}

To further understand the relationship between the adsorption capacity and the contact time, the adsorption kinetics were studied at a constant concentration [54]. Three kinetic models, namely the pseudo-first-order kinetic model, the pseudo-second-order kinetic model, and an intraparticle diffusion model, were expressed as follows:

$$
\begin{gathered}
\ln \left(q_{e}-q_{t}\right)=\ln q_{e}-k_{1} \times t \\
\frac{t}{q_{t}}=\frac{1}{k_{2} q_{e}^{2}}+\frac{t}{q_{e}} \\
q_{t}=k_{p} \times t^{\frac{1}{2}}+C
\end{gathered}
$$

where $q_{t}\left(\mathrm{mg} \mathrm{g}^{-1}\right)$ and $q_{e}\left(\mathrm{mg} \mathrm{g}^{-1}\right)$ represent the adsorption amount of $\mathrm{Cl}^{-}$at time $\mathrm{t}$ and at equilibrium time, respectively; $t$ represents the contact time $(\mathrm{min})$, and $k_{1}\left(\mathrm{~min}^{-1}\right)$ is the corresponding rate constant of the pseudo-first-order kinetic model. $k_{2}\left(\mathrm{~g} \mathrm{mg}^{-1} \mathrm{~min}^{-1}\right)$ is the corresponding rate constant of the pseudo-second-order kinetic model. $k p\left(\mathrm{mg} \mathrm{g}^{-1} \mathrm{~min}^{1 / 2}\right)$ is the distribution coefficient responding to the diffusion rate within the particle. $C$ is a constant of the particle diffusion [55] corresponding to the boundary layer thickness.

Figure 7a,b shows the fitting results of the pseudo-first-order kinetic model and the pseudo-second-order kinetic model under an adsorption temperature of $293 \mathrm{~K}$. The calculated parameters are listed in Table 3. As indicated in the results, the pseudo-second-order kinetic model has a higher value of the correlation coefficient $\left(R^{2}=0.99\right)$ compared with the pseudo-first-order kinetic model $\left(\mathrm{R}^{2}=0.98\right)$. Furthermore, the theoretical calculated adsorption capacity of the pseudo-second-order kinetic model $\left(q_{e}\right.$, cal $)$ was near to the value of experimental ( $\left.q_{e}, \exp \right)$. That is the pseudo-second-order kinetic model is the most suitable for describing the adsorption of $\mathrm{Cl}^{-}$. It was, therefore, suggested that the $\mathrm{Cl}^{-}$adsorption 
process involves chemical adsorption, which may relate the interactions between $\mathrm{Cl}^{-}$and the laminate of the $\mathrm{Mg}-\mathrm{Al} \mathrm{LDO}$ to this phenomenon.
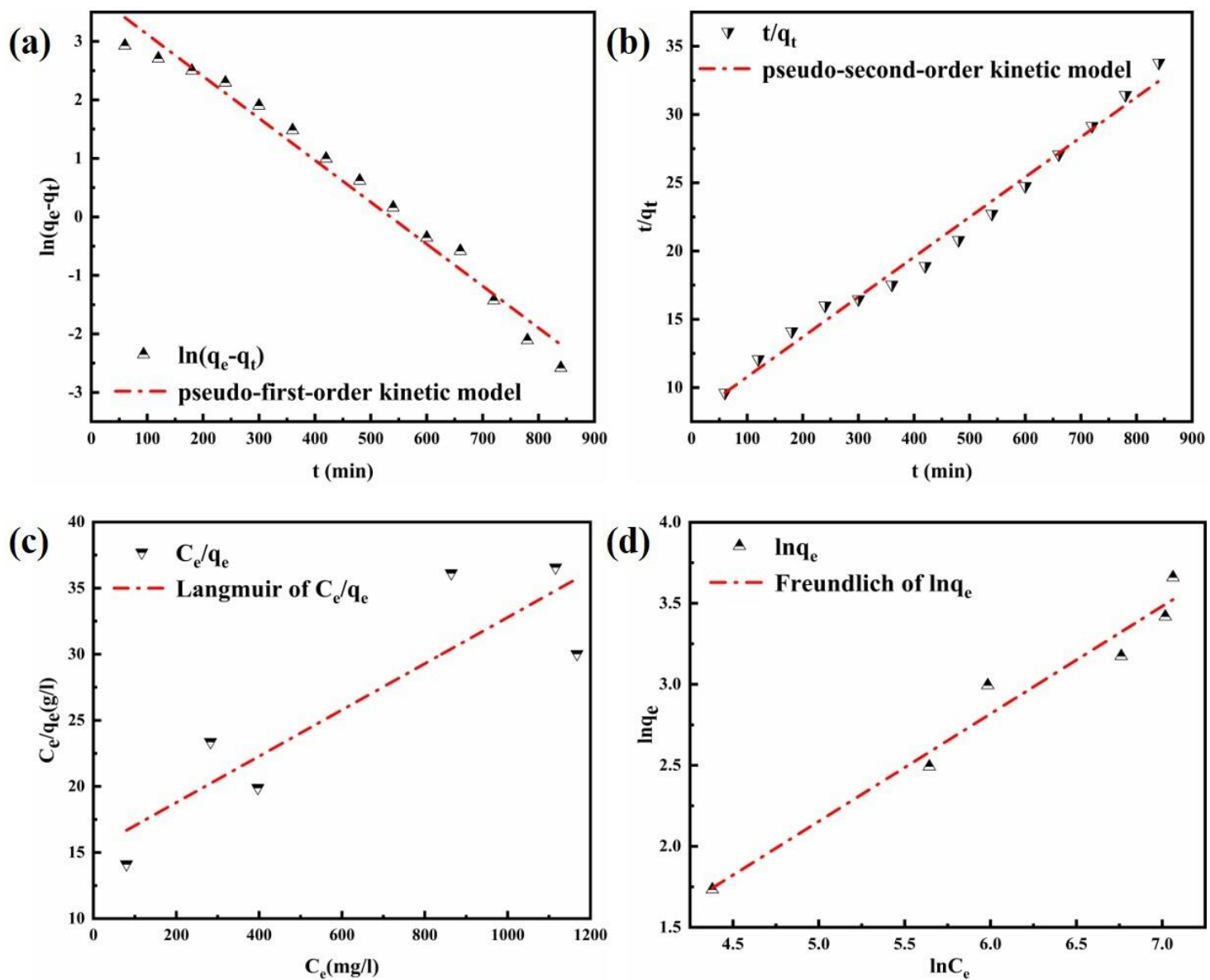

Figure 7. Diagram of (a) pseudo-first-order kinetic model and (b) pseudo-second-order kinetic model for the adsorption of $\mathrm{Cl}^{-}$on the LDO; (c) Langmuir model and (d) Freundlich model for the adsorption of $\mathrm{Cl}^{-}$on the LDO.

Table 3. Pseudo-first-order and pseudo-second-order kinetic model parameters.

\begin{tabular}{|c|c|c|c|c|c|c|}
\hline \multirow{2}{*}{$\begin{array}{r}\text { qe, exp } \\
\mathrm{mg} \mathrm{g}^{-1}\end{array}$} & \multicolumn{3}{|c|}{ Pseudo-First-Order Kinetic Model } & \multicolumn{3}{|c|}{ Pseudo-Second-Order Kinetic Model } \\
\hline & $k_{1}\left(\min ^{-1}\right)$ & qe $\left(\mathrm{mg} \mathrm{g}^{-1}\right)$ & $\mathbf{R}_{1}{ }^{2}$ & $k_{2}\left(g \mathrm{mg}^{-1} \min ^{-1}\right)$ & qe $\left(\mathrm{mg} \mathrm{g}^{-1}\right)$ & $\mathbf{R}_{2}{ }^{2}$ \\
\hline 24.94 & 0.01651 & 46.36 & 0.98 & 0.00011 & 34.14 & 0.99 \\
\hline
\end{tabular}

The adsorption results were used to simulate the intraparticle diffusion model. It is a diffusion phenomenon that controls the adsorption process when the fitting plot is linear. Figure 8 shows the plot of qt vs. $t^{1 / 2}$, and the parameters of the intraparticle diffusion model calculated are represented in Table 4 . The adsorption of $\mathrm{Cl}^{-}$is a complicated process because the linear plot does not pass through the origin. The first stage concerns the adsorption and diffusion of $\mathrm{Cl}^{-}$on the surface of the material. The diffusion rate is faster than expected. The second stage is related to the process of intraparticle diffusion. Taking into consideration the rate constants, it can be concluded that the secondary step was the rate controlling step in the process of adsorption. This may be due to the reduction in effective active sites and the resulting thicker boundary layer [56]. 


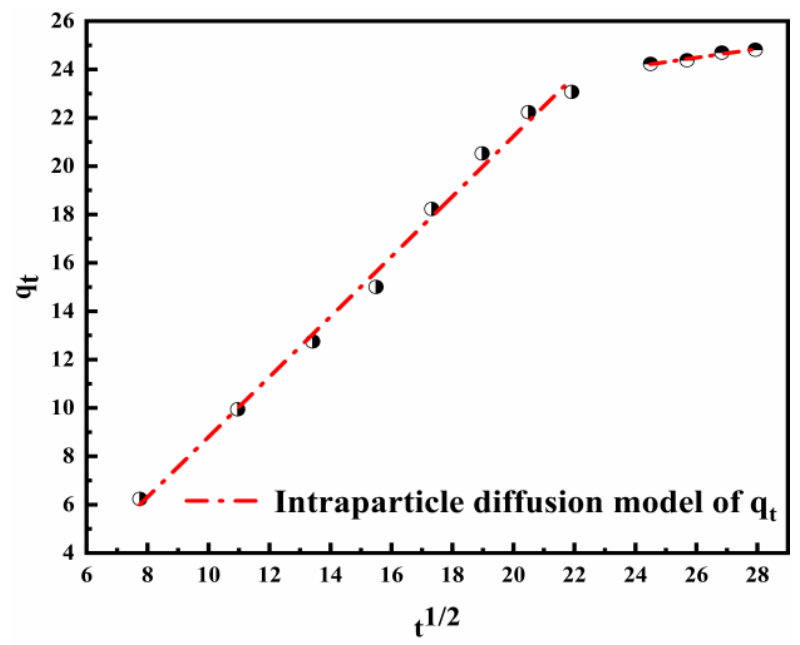

Figure 8. Diagram of the intraparticle diffusion model for the adsorption of $\mathrm{Cl}^{-}$on the $\mathrm{LDO}$.

Table 4. Parameters of the intraparticle diffusion model.

\begin{tabular}{cccccc}
\hline \multicolumn{7}{c}{ Intraparticle Diffusion Model } \\
\hline $\mathbf{k p}_{\mathbf{1}}\left(\mathbf{m g ~ g}^{-\mathbf{1}} \cdot \mathbf{m i n}^{\mathbf{1 / 2}}\right)$ & $\mathbf{C}_{\mathbf{1}}$ & $\mathbf{R}^{\mathbf{2}}$ & $\mathbf{k p}_{\mathbf{2}}\left(\mathbf{m g ~ g}^{-\mathbf{1}} \cdot \mathbf{m i n}^{\mathbf{1} \mathbf{2}}\right)$ & $\mathbf{C}_{\mathbf{2}}$ & $\mathbf{R}^{\mathbf{2}}$ \\
\hline 1.2434 & -3.6289 & 0.99 & 0.1802 & 19.8046 & 0.97 \\
\hline
\end{tabular}

\subsection{Adsorption Isotherm}

Simulating the experimental data using the Langmuir isotherm model and the Freundlich isotherm model can help us to further understand the mechanism of $\mathrm{Cl}^{-}$removal. The Langmuir isotherm assumes that, based on the monolayer adsorption, the adsorption of adsorbate molecules on the active site is uniform, while the Freundlich isotherm assumes the adsorption is multilayer and heterogeneous; the model is applicable to chemical adsorption $[25,55]$. The expressions of these models can be respectively presented as follows:

$$
\begin{gathered}
\frac{C_{e}}{q_{e}}=\frac{1}{q_{m} K_{L}}+\frac{C_{e}}{q_{m}} \\
\ln q_{e}=\ln K_{F}+\frac{1}{n} \times \ln C_{e}
\end{gathered}
$$

where $q_{e}\left(\mathrm{mg} \mathrm{g}^{-1}\right)$ and $q_{m}\left(\mathrm{~m} \mathrm{~mol} \mathrm{~g}^{-1}\right)$ represent the equilibrium capacity and the maximum adsorption capacity, respectively. $C_{e}\left(\mathrm{mg} \mathrm{L}^{-1}\right)$ represents the equilibrium of the $\mathrm{Cl}^{-}$concentration. The equilibrium adsorption constant $K L\left(\mathrm{~L} \mathrm{mg}^{-1}\right)$ is used to express the anions' affinity to the binding sites, the Freundlich constant $K F$ is associated with the adsorption capacity, and $n$ is named as the heterogeneity factor.

Comparing the Langmuir fitting results with the Freundlich isotherm models (as shown in Figure 7c,d and Table 5), it can be observed that the adsorption of $\mathrm{Cl}^{-}$onto the material better coincides with the Freundlich model $\left(R^{2}=0.96\right)$, indicating that there was a co-adsorption process [55]. Where the value of $n$ is greater than 1 , it can be concluded that sorption is favorable. After a combined analysis of the adsorption kinetics, it can be concluded that the adsorbent is appropriate when used in practical applications.

\begin{tabular}{|c|c|c|c|c|c|}
\hline \multicolumn{3}{|c|}{ Langmuir Isotherm Model } & \multicolumn{3}{|c|}{$\begin{array}{l}\text { Freundlich Isotherm Model } \\
\end{array}$} \\
\hline$Q_{0}\left(\mathrm{mg} \mathrm{g}^{-1}\right)$ & $\mathrm{KL}\left(\mathrm{L} \mathrm{mg}^{-1}\right)$ & $\mathbf{R}^{2}$ & $\mathrm{KF}\left(\mathrm{mg} \mathrm{g}^{-1}\right)\left(\mathrm{L} \mathrm{mg}^{-1}\right)^{1 / n}$ & $n$ & $\mathbf{R}^{2}$ \\
\hline 57.14 & 0.0011 & 0.78 & 0.312 & 1.51 & 0.96 \\
\hline
\end{tabular}

Table 5. Langmuir and Freundlich isotherm model parameters. 
The thermodynamic data can be calculated using the following equations:

$$
\begin{gathered}
K=\frac{C_{0}-C_{e}}{C_{e}} \\
\ln K=\frac{\Delta S^{0}}{R}-\frac{\Delta H^{0}}{R T} \\
\Delta G^{0}=-R T \ln K
\end{gathered}
$$

$K$ is the equilibrium constant of the process, and $R\left(\mathrm{~J} \mathrm{~mol}^{-1} \mathrm{~K}^{-1}\right)$, with a value of 8.314 , is the universal gas constant. $\Delta G^{0}\left(\mathrm{~kJ} \mathrm{~mol}^{-1}\right)$ represents the change in free energy, $\Delta S^{0}$ $\left(\mathrm{J} \mathrm{mol} \mathrm{K}{ }^{-1}\right)$ is entropy change, and $\Delta H^{0}$ is enthalpy change.

Results are displayed in Table S5. The value of $\Delta G^{0}$ was negative, and it suggests that the removal process was spontaneous. The positive $\Delta H^{0}$ indicates the endothermic parts of this process, and the negative value of $\Delta S^{0}$ confirms that the degree of chaos had increased. In the process of chloride ion removal, $\mathrm{Cl}^{-}$was absorbed to reconstruct the bimetallic hydroxide layered structure and the action of ion exchange further enhanced the process.

\subsection{Recyclability of LDO Adsorbents}

The reusability of the adsorbent is an important indicator of whether the adsorbent is economical. Thus, its reusability was assessed by conducting repetitive experiments within the same conditions. Figure 9 shows the recycling time on $\mathrm{Cl}^{-}$removal in the wastewater. $\mathrm{Mg}-\mathrm{Al} \mathrm{LDO}$ was recovered in the layered structure in the aqueous solution, which provides more active sites for the adsorption of $\mathrm{Cl}^{-}$. In this work, $\mathrm{Mg}-\mathrm{Al} \mathrm{LDO} \mathrm{Cl}{ }^{-}$ was calcinated at $480^{\circ} \mathrm{C}$ to obtain the adsorbent and then the re-calcinated adsorbent was used for $\mathrm{Cl}^{-}$adsorption again, within the same conditions. The Mg-Al LDO still exhibited good adsorption performance (more than $90 \%$ ) for $\mathrm{Cl}^{-}$after 11 adsorption-desorption cycles. This indicates that the synthesized LDO has a good recycling performance and can reduce the costs of the process to a certain extent. Compared to other materials, the $\mathrm{Mg}-\mathrm{Al} \mathrm{LDO}$ has the highest $\mathrm{Cl}^{-}$removal efficiency (Table 6). The restoration of the layered structure and the combined action of ion exchange allow for better removal of $\mathrm{Cl}^{-}$. The different synthesis method and the experimental environment may result in different properties of materials. Therefore, the Mg-Al LDO studied in this work exhibits better removal efficiency of $\mathrm{Cl}^{-}$.

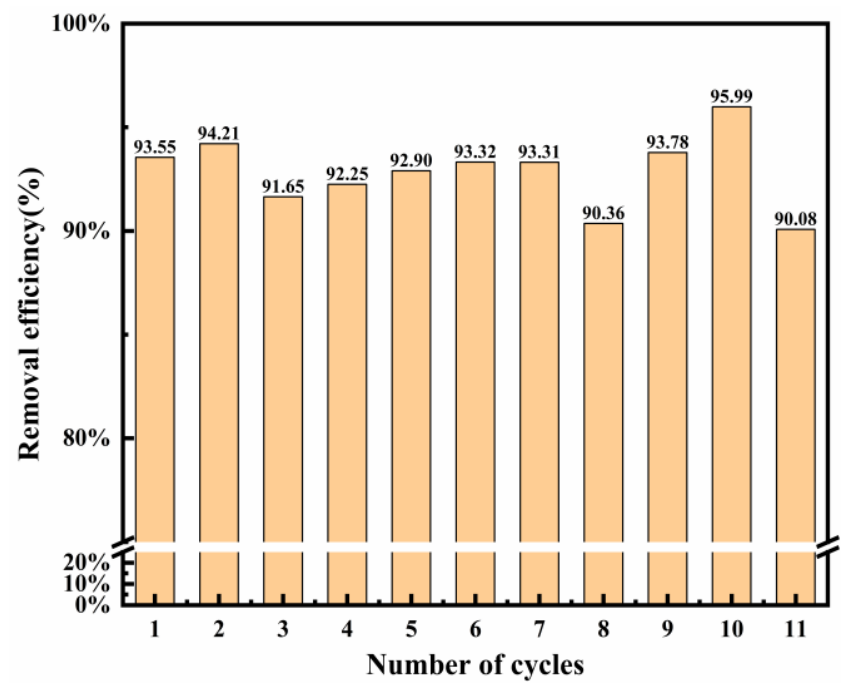

Figure 9. Reusability of LDO (calcinated at $480{ }^{\circ} \mathrm{C}$ ) on $\mathrm{Cl}^{-}$adsorption $\left(\mathrm{Cl}^{-}\right.$initial concentration: $2000 \mathrm{mg} \mathrm{L}^{-1}$; adsorbent dosage: $2 \mathrm{~g}$; adsorption temperature: $293 \mathrm{~K}$; contact time: $13 \mathrm{~h}$ ). 
Table 6. Comparative study of the removal efficiency of LDO against other reported sorbents for $\mathrm{Cl}^{-}$.

\begin{tabular}{ccc}
\hline Sorbent & Removal Efficiency & Reference \\
\hline $\mathrm{Mg}_{0.80} \mathrm{Al}_{0.20} \mathrm{O}_{1.1}$ & $14.95 \%$ & {$[42]$} \\
Double hydrous oxide $\left(\mathrm{Fe}_{2} \mathrm{O}_{3} \cdot \mathrm{Al}_{2} \mathrm{O}_{3} \cdot \mathrm{xH}_{2} \mathrm{O}\right)$ & $23.93 \%$ & {$[57]$} \\
$\mathrm{Zn}-\mathrm{Al}$ oxide $(\mathrm{Zn} / \mathrm{Al}=3.0)$ & $32 \%$ & {$[44]$} \\
$\mathrm{Mg}-\mathrm{Al}$ oxide $(\mathrm{Mg} / \mathrm{Al}=3.0)$ & $75.41 \%$ & {$[58]$} \\
$\mathrm{Mg}-\mathrm{Al}$ oxide $(\mathrm{Mg} / \mathrm{Al}=3.0)$ & $96 \%$ & {$[44]$} \\
$\mathrm{Mg}-\mathrm{Al} \mathrm{LDO}(\mathrm{Mg} / \mathrm{Al}=6.0)$ & $97.09 \%$ & This work \\
\hline
\end{tabular}

\subsection{Mechanism for $\mathrm{Cl}^{-}$Removal}

XRD patterns of the $\mathrm{Mg}-\mathrm{Al} \mathrm{LDH}$ precursor, $\mathrm{Mg}-\mathrm{Al} \mathrm{LDO}$, and $\mathrm{Mg}-\mathrm{Al} \mathrm{LDO} \mathrm{Cl}^{-}$are demonstrated in Figure 10a. The XRD pattern of the $\mathrm{Mg}-\mathrm{Al} \mathrm{LDO} \mathrm{Cl}{ }^{-}$is akin to that of the precursor, presenting the typical peaks of hydrotalcite. However, (003), (006), (015), and other characteristic peaks corresponding to $\mathrm{Mg}-\mathrm{Al} \mathrm{LDO}$ have disappeared, showing the characteristic peak of the metal oxide [47]. The characteristic peaks of hydrotalcite have reappeared in $\mathrm{Mg}-\mathrm{Al} \mathrm{LDO} \mathrm{Cl}^{-}$, which is consistent with the reconstruction of the layered structure [59]. It is observed that the reflection of (003) has shifted to a higher $2 \theta$ angle and that the d-spacing has decreased from $0.793 \mathrm{~nm}$ for $\mathrm{Mg}-\mathrm{Al} \mathrm{LDH}$ to $0.786 \mathrm{~nm}$ for $\mathrm{Mg}-\mathrm{Al}$ $\mathrm{LDO} \mathrm{Cl}^{-}$(as shown in Table S2). The smaller size of the intercalated anion of Mg-Al LDO $\mathrm{Cl}^{-}$is clearly seen when compared to the $\mathrm{Mg}-\mathrm{Al} \mathrm{LDH}$ precursor $[31,60]$. The thickness of the laminate was $0.48 \mathrm{~nm}$ [61], and the gallery height of the samples can be achieved by subtracting the thickness of the metal hydroxide laminate from the interlayer spacing, which is approximately $0.313 \mathrm{~nm}$ for the $\mathrm{Mg}-\mathrm{Al} \mathrm{LDH}$ precursor, while for $\mathrm{Mg}-\mathrm{Al} \mathrm{LDO} \mathrm{Cl}{ }^{-}$, it is $0.306 \mathrm{~nm}$ and is larger than the ion radius of chloride $(0.167 \mathrm{~nm})$. It can be concluded that the space resistance of chloride is small during the process of entering the laminate to reconstruct the layer structure. At the same time, it provides the right conditions for multi-layer adsorption of $\mathrm{Cl}^{-}$. From the results of $\mathrm{N}_{2}$ adsorption-desorption, sufficient pore volume and larger average pore diameter can be observed and expose more active sites, which provide favorable conditions for $\mathrm{Cl}^{-}$adsorption. The diagram of the SEM spectrum can also confirm this conclusion (as shown in Figure 11c). The lattice parameters of the samples a and c are given in Table S2.
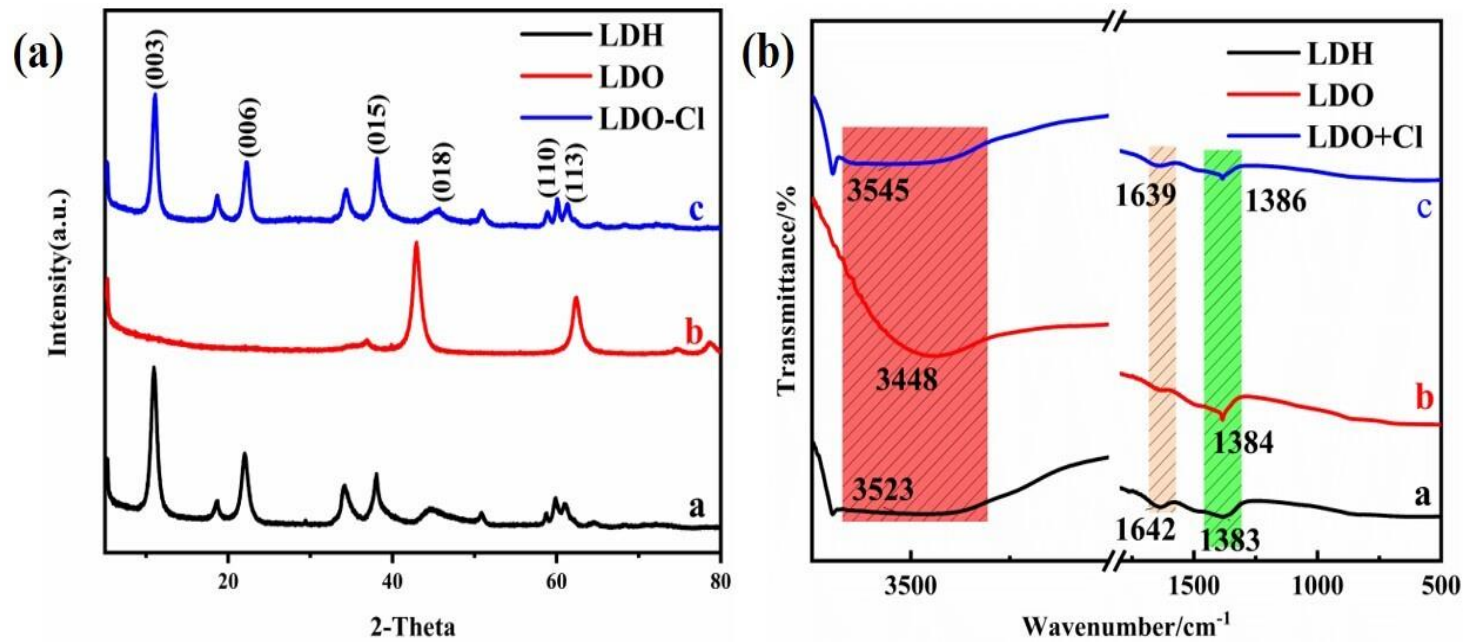

Figure 10. (a) X-ray diffraction analysis; (b) FT-IR spectra of the samples. 


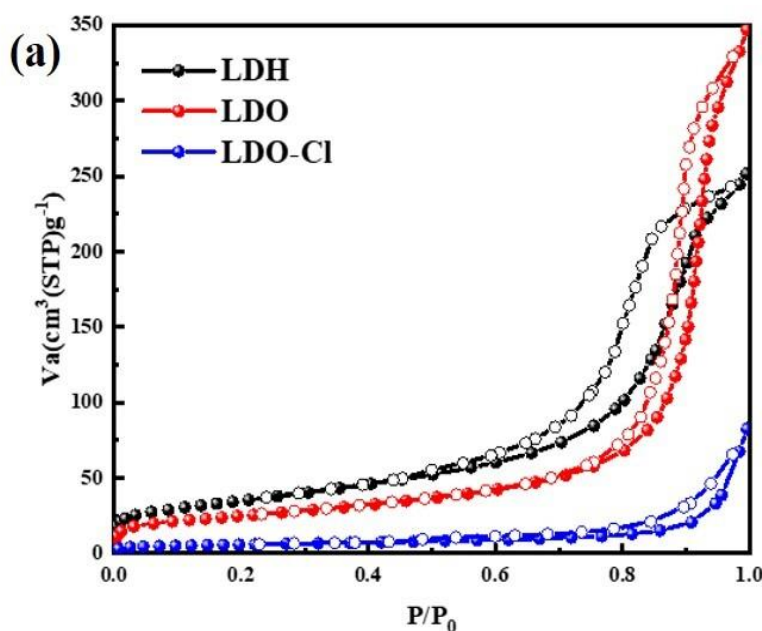

(b)

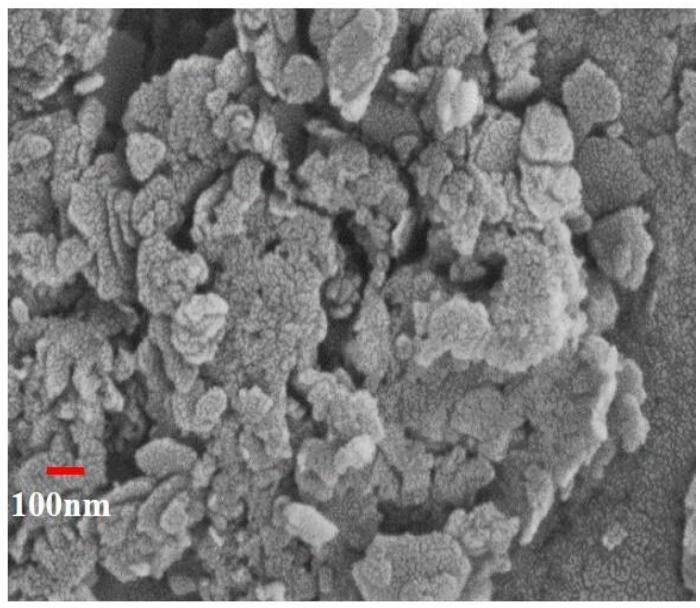

(c)

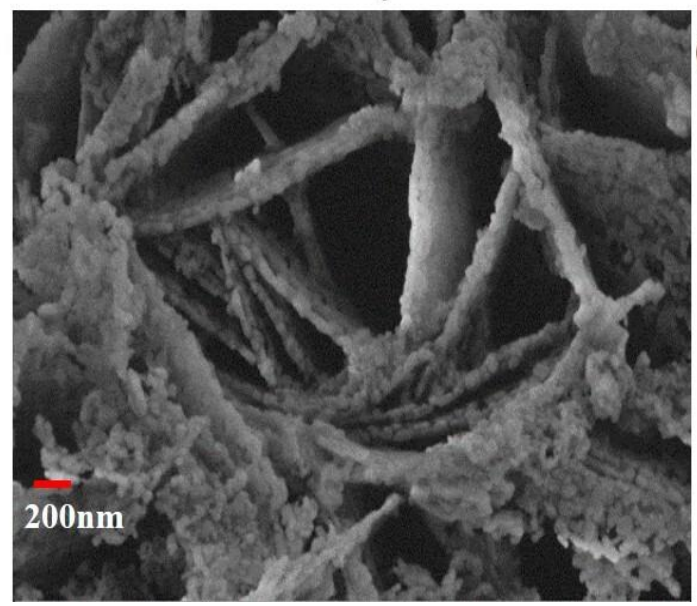

(d)

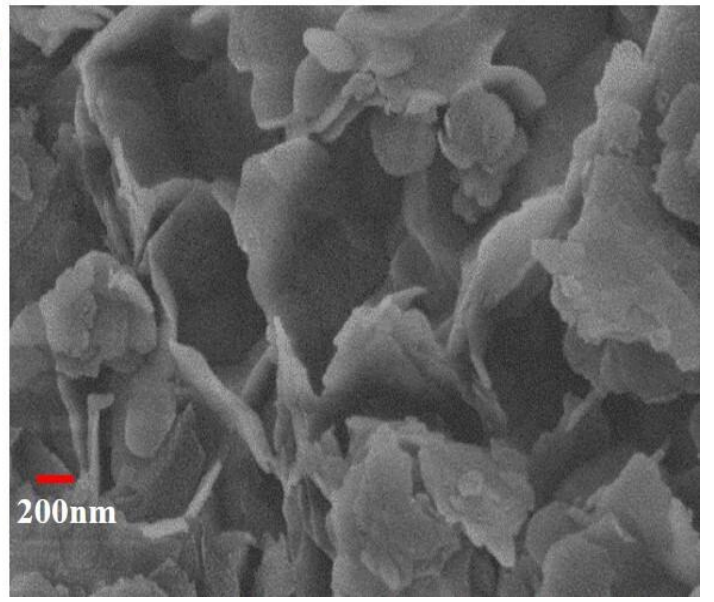

Figure 11. (a) $\mathrm{N}_{2}$ adsorption-desorption isotherms; (b-d) SEM images of the samples.

The FT-IR spectra of the samples are displayed in Figure 10b. In all the samples, broad intense bands observed around $3448-3545 \mathrm{~cm}^{-1}$ are associated with the stretching vibration of the hydroxyl groups $[45,62]$, and the characteristic absorption band around $1385 \mathrm{~cm}^{-1}$ is scribed to the antisymmetric stretching mode of $\mathrm{NO}_{3}{ }^{-}$in the interlayer [30]. Characteristic peaks shown at $1640 \mathrm{~cm}^{-1}$ are attributed to the bending vibration of the interlayer molecular water [63], which was lost after the calcination process. This confirms the decomposition of the interlayer water. In addition, the slight decrease in $1385 \mathrm{~cm}^{-1}$ implies that there is a partial decomposition of the interlayer anions. After the adsorption of $\mathrm{Cl}^{-}$, the band at $1383 \mathrm{~cm}^{-1}$ shifts to higher frequencies (to $1386 \mathrm{~cm}^{-1}$ ). This may be explained by the influence of $\mathrm{Cl}^{-}$on its reconstructed structure. The bending vibration of molecular water reappears at $1639 \mathrm{~cm}^{-1}$, and the schematic diagram of the FT-IR spectrum is similar to that of the precursor, which demonstrates that the layer structure has been well reconstructed.

Figure 11a shows the $\mathrm{N}_{2}$ adsorption-desorption isotherms of materials. Nitrogen adsorption-desorption isotherms were used to examine the surface area and porosity of the $\mathrm{Mg}-\mathrm{Al} \mathrm{LDH}$ precursor, the $\mathrm{Mg}-\mathrm{Al} \mathrm{LDO}$ adsorbent, and $\mathrm{Mg}-\mathrm{Al} \mathrm{LDO} \mathrm{Cl}{ }^{-}$samples. As shown in Table S3, the total pore volume and the average pore diameter of $\mathrm{Mg}$-Al LDO were $0.5261 \mathrm{~cm}^{3} \mathrm{~g}^{-1}$ and $23.958 \mathrm{~nm}$, while the measurements for $\mathrm{Mg}-\mathrm{Al} \mathrm{LDH}$ were $0.3843 \mathrm{~cm}^{3} \mathrm{~g}^{-1}$ and $12.269 \mathrm{~nm}$. An obvious increase in the total pore volume and porosity of $\mathrm{Mg}-\mathrm{Al} \mathrm{LDO}$ was observed, which provides a favorable condition for $\mathrm{Cl}^{-}$adsorption. The specific surface area of Mg-Al LDH $\left(87.84 \mathrm{~m}^{2} \mathrm{~g}^{-1}\right)$ increased to $125.27 \mathrm{~m}^{2} \mathrm{~g}^{-1}$ after calcination and decreased again to $20.253 \mathrm{~m}^{2} \mathrm{~g}^{-1}$ after $\mathrm{Cl}^{-}$adsorption. Similar trends were seen in the total pore volume and the average pore diameter after the adsorption of $\mathrm{Cl}^{-}$on $\mathrm{Mg}-\mathrm{Al}$ LDO (as shown in Table S2). The significant decrease in the specific surface area of 
$\mathrm{Mg}-\mathrm{Al} \mathrm{LDO} \mathrm{Cl}{ }^{-}$when compared to $\mathrm{Mg}-\mathrm{Al} \mathrm{LDH}$ is borne by different anion species in the interlayer and by the transformation of the crystal structure.

According to the IUPAC classification [51], a type IV isotherm and an $\mathrm{H} 2$ hysteresis loop can be observed of the precursor (as shown in Figure 11a). The presence of mesopores and capillary condensation is the cause of this phenomenon [64,65]. For Mg-Al LDO, a narrow adsorption-desorption hysteresis loop was observed when the relative pressure was above 0.7 . This hysteresis loop was determined to be a type $\mathrm{H} 1$ hysteresis loop with typical tubular capillary pores. After the adsorption of $\mathrm{Cl}^{-}$, the $\mathrm{Mg}-\mathrm{Al} \mathrm{LDO} \mathrm{Cl}^{-}$material exhibits type III adsorption isotherms and type $\mathrm{H3}$ adsorption loops [66]. This indicates that the pore structure of the $\mathrm{Mg}-\mathrm{Al} \mathrm{LDO}$ material after the adsorption of $\mathrm{Cl}^{-}$includes cleavage-type pores, which are formed by the accumulation of mutually inclined sheets. The description of this phenomenon is consistent with the results of the scanning electron microscope test. The structure of the material changes after the adsorption of chloride ions, indicating that the reconstruction of the layer structure plays an important role in the removal of $\mathrm{Cl}^{-}$.

Figure $11 \mathrm{~b}$ shows the SEM measurement of the Mg-Al LDH precursor. Figure $11 \mathrm{c}$ shows the SEM measurement of the Mg-Al LDO, and Figure 11d shows the SEM measurement of the $\mathrm{Mg}-\mathrm{Al} \mathrm{LDO} \mathrm{Cl}{ }^{-}$. These clearly show that the structure of the precursor is stacked in layers. The pores between the Mg-Al LDO layers were detected after calcination, which provides favorable conditions for the removal of $\mathrm{Cl}^{-}$and is consistent with the calculation result of BET. The irregular and flaky and loose stacking structure of $\mathrm{Mg}-\mathrm{Al}$ $\mathrm{LDO} \mathrm{Cl}{ }^{-}$was observed after the adsorption of $\mathrm{Cl}^{-}$.

Figure S5 shows the thermal gravimetric analysis of Mg-Al LDH. Three stages of weight loss were observed. The first weight loss stage $(14.62 \%)$ occurred between room temperature and $245^{\circ} \mathrm{C}$, where adsorbed water on the crystallite surface and crystallized water between the cationic layers were removed. The second weight loss stage $(18.17 \%)$, which occurred between 245 and $343{ }^{\circ} \mathrm{C}$, is associated with the thermal decomposition of the hydroxyl $\left(\mathrm{OH}^{-}\right)$groups and accompanied the decomposition of part of nitrate $\left(\mathrm{NO}_{3}{ }^{-}\right)$ species. Finally, the last stage of weight loss $(15.51 \%)$ occurred from $343{ }^{\circ} \mathrm{C}$ to $700{ }^{\circ} \mathrm{C}$ and corresponds to the loss of nitrate species [45].

The zeta potential has a significant impact on a suspension's stability. This is because it can provide precise information about the reason for dispersion or aggregation, which has become one of the most important factors influencing the stability of the suspension [50]. The zeta potential of the Mg-Al LDO is positively charged at $6.8 \mathrm{mv}$ (as shown in Table S4). Due to the low surface electrical properties, $\mathrm{Cl}^{-}$can be accelerated into entering the interlayer. After stabilization, the zeta potential of the $\mathrm{Mg}-\mathrm{Al} \mathrm{LDO} \mathrm{Cl}^{-}$increases to $37.12 \mathrm{mv}$, indicating that the $\mathrm{Mg}-\mathrm{Al} \mathrm{LDO} \mathrm{Cl}{ }^{-}$is much more stable.

The comparative adsorption capacity and anion exchange capacity is shown in Table S6. It can be clearly observed that the adsorption capacity is larger than the anion exchange capacity. That is, the synergistic effect of the reconstruction of the layered structure and the ion exchange enables a more efficient removal of $\mathrm{Cl}^{-}$. It is the adsorption of negative anions to reconstruct the layer structure that dominates the process.

According to the experimental results of adsorption properties and systematically characterization, the process of $\mathrm{Cl}^{-}$removal can be described as follows (as illustrated in Figure 12): the positively charged surface of Mg-Al LDO enhances the electrostatic attraction between the adsorbent and the negatively charged $\mathrm{Cl}^{-}$. Sufficient pore volume and larger average pore diameter expose more active sites, which provide favorable conditions for $\mathrm{Cl}^{-}$adsorption. During the reconstruction process, it is deduced that some $\mathrm{Cl}^{-}$adsorbed on the edge rebuild the layer structure first. With the enhanced electrostatic attraction provided by the high charge density laminate, other $\mathrm{Cl}^{-}$enter the layer and are exchanged with the remaining $\mathrm{NO}_{3}{ }^{-}$, resulting in the efficient removal of $\mathrm{Cl}^{-}$. 


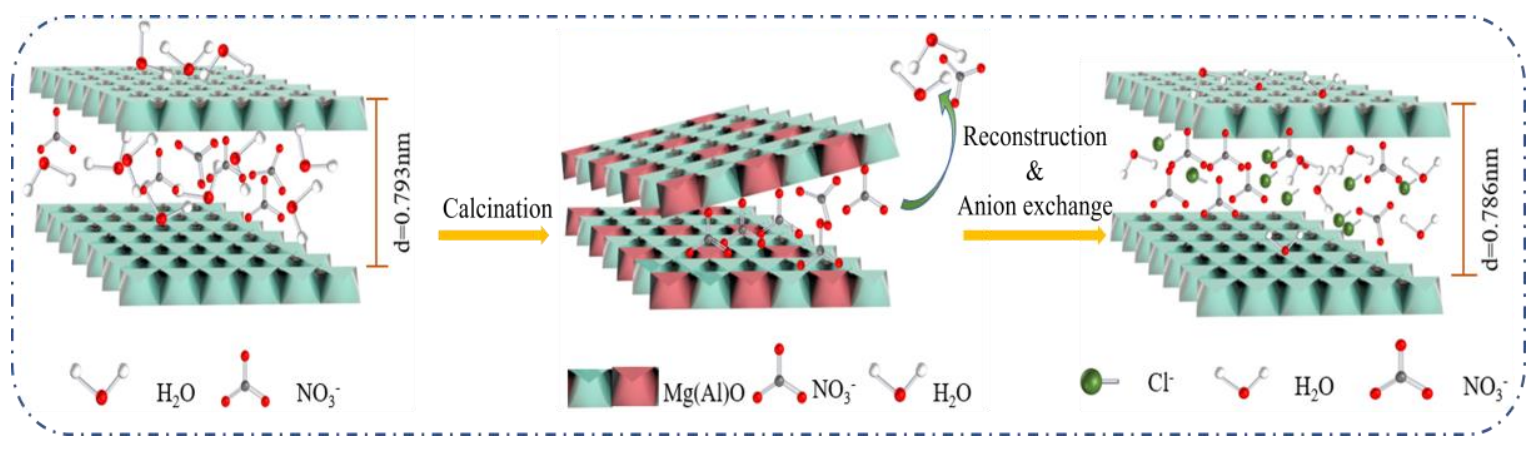

Figure 12. Schematic diagram of the removal mechanism of Mg-Al LDO.

\section{Conclusions}

In this paper, a Mg-Al LDH precursor was successfully synthesized using an improved coprecipitation method, which considered the effect of $\mathrm{M}^{2+} / \mathrm{M}^{3+}$. The $\mathrm{Mg}-\mathrm{Al} \mathrm{LDO}$ adsorbent was obtained by the calcination of the precursor. The characterization results showed that the adsorbent had a rich pore structure, that $\mathrm{Cl}^{-}$successfully entered the interlayer bonding the laminate to reconstruct the layered structure, and exchange with nitrate remained in the interlayer. The adsorption experimental results suggest that the $\mathrm{Mg}-\mathrm{Al} \mathrm{LDO}$ material exhibits a significant adsorption capacity for $\mathrm{Cl}^{-}$. The experiments found that the optimal contact time is $13 \mathrm{~h}$. The optimized dosage of adsorbent is $80 \mathrm{~g} \mathrm{~L}^{-1}$, and the value of the adsorption capacity is up to $24.82 \mathrm{mg} \mathrm{g}^{-1}$. Additionally, the $\mathrm{Cl}^{-}$ adsorption on to the Mg-Al LDO fits well with the pseudo-second-order model and the Freundlich model. Overall, the adsorbent exhibited a better regeneration performance too. In conclusion, $\mathrm{Mg}-\mathrm{Al} \mathrm{LDO}$ is a promising material for $\mathrm{Cl}^{-}$elimination.

Supplementary Materials: The following supporting information can be downloaded at: https:/ / www.mdpi.com/article/10.3390/nano12050846/s1, Figure S1: $\mathrm{Cl}^{-}$removal efficiency and adsorption capacity, as a function of the calcination temperature (adsorbent dosage: $2 \mathrm{~g} ; \mathrm{Cl}^{-}$initial concentration: $2000 \mathrm{mg} \mathrm{L}^{-1}$, adsorption temperature: $293 \mathrm{~K}$, contact time: $13 \mathrm{~h}$ ); Figure S2: $\mathrm{Cl}^{-}$removal efficiency and adsorption capacity, as a function of the calcination time (calcination temperature: $480^{\circ} \mathrm{C}$, adsorbent dosage: $2 \mathrm{~g}$; $\mathrm{Cl}^{-}$initial concentration: $2000 \mathrm{mg} \mathrm{L}^{-1}$, adsorption temperature: $293 \mathrm{~K}$, contact time: 13 h); Figure S3: EDS images of (a) LDH-2: 1; (b) LDH-3: 1; (c) LDH-4: 1; (d) LDH-5: 1; (e) LDH-6: 1; Figure S4: Preparation process of Mg-Al-LDO; Figure S5: TGA curve of Mg-Al$\mathrm{LDH}$; pristine LDH; Figure S6: Standard curve of $\mathrm{Cl}^{-}$determined by Ion Chromatograph; Table S1: Concentration ratio of $\mathrm{Mg} / \mathrm{Al}$ in different samples; Table S2: XRD Parameters of Mg-Al-LDH, MgAl-LDO and Mg-Al-LDO-Cl ${ }^{-}$; Table S3: Specific surface area, total pore volume, and average pore diameter of Mg-Al-LDH, Mg-Al-LDO, Mg-Al-LDO-Cl- ${ }^{-}$Table S4: Zeta potential of Mg-Al-LDH, Mg-Al-LDO, Mg-Al-LDO-Cl- ; Table S5: Thermodynamic data of chloride adsorption; Table S6: Comparative of adsorption capacity and anion-exchange capacity on $\mathrm{Cl}^{-}$removal.

Author Contributions: Investigation, formal analysis, data curation, and writing-original draft preparation, X.X.; methodology and software, P.L. and T.Z.; writing-review and editing, S.Y. and X.H.; conceptualization, validation, and funding acquisition, Y.C., G.Z. and D.T. All authors have read and agreed to the published version of the manuscript.

Funding: This research was financially supported by the Nation Key Research and Development Program of China [No. 2020YFC1908801; No. 2021YFC2901300]; the Program for Innovative Research Team (in Science and Technology) in University of Henan Province [No. 19IRTSTHN028]; Natural Science Foundation of China [No. 51904274].

Data Availability Statement: All the data is available in this manuscript.

Acknowledgments: The authors gratefully acknowledge the financial support for this research by the National Key Research and Development Program [No. 2020YFC1908801, No. 2021YFC2901300]; the Program for Innovative Research Team (in Science and Technology) at the University of Henan Province [No. 19IRTSTHN028]; Natural Science Foundation of China [No. 51904274], and Center for Modern Analysis and Gene Sequencing in Zhengzhou University. 
Conflicts of Interest: The authors declare no conflict of interest.

\section{References}

1. Wang, X.; Du, Y.; Yang, H.; Tian, S.; Ge, Q.; Huang, S.; Wang, M. Removal of chloride ions from acidic solution with antimony oxides. J. Ind. Eng. Chem. 2021, 93, 170-175. [CrossRef]

2. Chang, J.; Li, Y.; Duan, F.; Su, C.; Li, Y.; Cao, H. Selective removal of chloride ions by bismuth electrode in capacitive deionization Sep. Purif. Technol. 2020, 240, 116600. [CrossRef]

3. Fang, P.; Tang, Z.; Chen, X.; Huang, J.; Tang, Z.; Cen, C. Chloride Ion Removal from the Wet Flue Gas Desulfurization and Denitrification Wastewater Using Friedel's Salt Precipitation Method. J. Chem. 2018, 2018, 5461060. [CrossRef]

4. Lu, J.; Ma, M.; Li, D.; Xu, S. Experimental Study on Chloride Ion Removal in High-Salt Wastewater System. IOP Conf. Ser. Earth Environ. Sci. 2020, 495, 1206495. [CrossRef]

5. Nam, D.; Lee, D.; Choi, K.S. Electrochemical and photoelectrochemical approaches for the selective removal, recovery, and valorization of chloride ions. Chem. Eng. J. 2020, 404, 126378. [CrossRef]

6. Huang, S.; Li, L.; Zhu, N.; Lou, Z.; Liu, W.; Cheng, J.; Wang, H.; Luo, P.; Wang, H. Removal and recovery of chloride ions in concentrated leachate by Bi(III) containing oxides quantum dots/two-dimensional flakes. J. Hazard. Mater. 2020, $382,121041$. [CrossRef] [PubMed]

7. Słowik, K.; Stec, M.; Iluk, T.; Czaplicki, A.; Kochel, M. Reduction of chloride emission by thickening of metallurgical wastewater. E3S Web Conf. 2019, 100, 00074. [CrossRef]

8. $\quad$ Li, Z.; Li, R.; Zhong, Z.; Zhou, M.; Chen, M.; Xing, W. Acid precipitation coupled electrodialysis to improve separation of chloride and organics in pulping crystallization mother liquor. Chin. J. Chem. Eng. 2019, 27, 2917-2924. [CrossRef]

9. Kameda, T.; Fukushima, S.; Shoji, C.; Grause, G.; Yoshioka, T. Electrodialysis for NaCl/EG solution using ion-exchange membranes. J. Mater. Cycles Waste Manag. 2013, 15, 111-114. [CrossRef]

10. Zhang, Z.; Hu, Y.-B.; Ruan, W.; Ai, H.; Yuan, B.; Fu, M.-L. Highly improved dechlorination of 2,4-dichlorophenol in aqueous solution by Fe/Ni nanoparticles supported by polystyrene resin. Chemosphere 2021, 266, 128976. [CrossRef]

11. Peng, W.; Li, H.; Liu, Y.; Song, S. A review on heavy metal ions adsorption from water by graphene oxide and its composites. J. Mol. Liq. 2017, 230, 496-504. [CrossRef]

12. Jawed, A.; Saxena, V.; Pandey, L. Engineered nanomaterials and their surface functionalization for the removal of heavy metals: A review. J. Water Process Eng. 2020, 33, 101009. [CrossRef]

13. Donneys-Victoria, D.; Marriaga-Cabrales, N.; Machuca-Martínez, F.; Benavides-Guerrero, J.; Cloutier, S.G. Indigo carmine and chloride ions removal by electrocoagulation. Simultaneous production of brucite and layered double hydroxides. J. Water Process Eng. 2020, 33, 101106. [CrossRef]

14. Guo, Y.; Zhu, Z.; Qiu, Y.; Zhao, J. Enhanced adsorption of acid brown 14 dye on calcined Mg/Fe layered double hydroxide with memory effect. Chem. Eng. J. 2013, 219, 69-77. [CrossRef]

15. Ramos-Ramírez, E.; Gutiérrez-Ortega, N.L.; Tzompantzi-Morales, F.; Barrera-Rodríguez, A.; Castillo-Rodríguez, J.C.; TzompantziFlores, C.; Santolalla-Vargas, C.E.; Guevara-Hornedo, M.D.P. Photocatalytic Degradation of 2,4-Dichlorophenol on NiAl-Mixed Oxides Derivatives of Activated Layered Double Hydroxides. Top. Catal. 2020, 63, 546-563. [CrossRef]

16. Yang, J.; Li, C.; Liang, D.; Liu, Y.; Li, Z.; Wang, H.; Huang, H.; Xia, C.; Zhao, H.; Liu, Y.; et al. Central-collapsed structure of CoFeAl layered double hydroxides and its photocatalytic performance. J. Colloid Interface Sci. 2021, 590, 571-579. [CrossRef]

17. Patel, R.; Inamdar, A.I.; Hou, B.; Cha, S.; Ansari, A.T.; Gunjakar, J.L.; Im, H.; Kim, H. Solvothermal synthesis of high-performance Ni-Co layered double hydroxide nanofoam electrode for electrochemical energy storage. Curr. Appl. Phys. 2017, 17, 501-506. [CrossRef]

18. Yin, Q.; Rao, D.; Zhang, G.; Zhao, Y.; Han, J.; Lin, K.; Zheng, L.; Zhang, J.; Zhou, J.; Wei, M. CoFe-Cl Layered Double Hydroxide: A New Cathode Material for High-Performance Chloride Ion Batteries. Adv. Funct. Mater. 2019, 29, 1900983. [CrossRef]

19. Kameda, T.; Horikoshi, K.; Kikuchi, H.; Kitagawa, F.; Kumagai, S.; Saito, Y.; Kondo, M.; Jimbo, Y.; Yoshioka, T. Kinetic and equilibrium analyses of lactate adsorption by $\mathrm{Cu}-\mathrm{Al}$ and $\mathrm{Mg}-\mathrm{Al}$ layered double hydroxides $(\mathrm{Cu}-\mathrm{Al} \mathrm{LDH}$ and $\mathrm{Mg}-\mathrm{Al} \mathrm{LDH})$ and $\mathrm{Cu}-\mathrm{Al}$ and Mg-Al layered double oxides (Cu-Al LDO and Mg-Al LDO). Nano-Struct. Nano-Objects 2021, 25, 100656. [CrossRef]

20. Santamaría, L.; Vicente, M.; Korili, S.; Gil, A. Progress in the removal of pharmaceutical compounds from aqueous solution using layered double hydroxides as adsorbents: A review. J. Environ. Chem. Eng. 2020, 8, 104577. [CrossRef]

21. Panplado, K.; Subsadsana, M.; Srijaranai, S.; Sansuk, S. Rapid Removal and Efficient Recovery of Tetracycline Antibiotics in Aqueous Solution Using Layered Double Hydroxide Components in an In Situ-Adsorption Process. Crystals 2019, 9, 342. [CrossRef]

22. Sui, M.; Zhou, Y.; Sheng, L.; Duan, B. Adsorption of norfloxacin in aqueous solution by Mg-Al layered double hydroxides with variable metal composition and interlayer anions. Chem. Eng. J. 2012, 210, 451-460. [CrossRef]

23. Jiang, J.; Ashekuzzaman, S.; Hargreaves, J.S.J.; McFarlane, A.R.; Badruzzaman, A.B.M.; Tarek, M.H. Removal of Arsenic (III) from groundwater applying a reusable $\mathrm{Mg}-\mathrm{Fe}-\mathrm{Cl}$ layered double hydroxide. J. Chem. Technol. Biotechnol. 2015, 90, 1160-1166. [CrossRef]

24. Yang, X.; Osawa, H.; Kameda, T.; Masaki, Y.; Saito, Y.; Kumagai, S.; Yoshioka, T. Continuous treatment of abandoned mine wastewater containing As and Fe using Mg-Al layered double hydroxides with flocculation. Int. J. Environ. Sci. Technol. 2021, 18, 4037-4042. [CrossRef] 
25. Ma, W.; Chen, Y.; Zhang, W.; Zhao, W. Performance and mechanism of Mg-Ca-Fe hydrotalcite-like compounds for fluoride removal from aqueous solution. J. Fluor. Chem. 2017, 200, 153-161. [CrossRef]

26. Wei, L.; Zietzschmann, F.; Rietveld, L.C.; van Halem, D. Fluoride removal from water by Ca-Al-CO 3 layered double hydroxides and simultaneous acidification. J. Water Process Eng. 2021, 40, 101957. [CrossRef]

27. Li, Y.; Bi, H.-Y.; Mao, X.-M.; Liang, Y.-Q.; Li, H. Adsorption behavior and mechanism of core-shell magnetic rhamnolipid-layered double hydroxide nanohybrid for phenolic compounds from heavy metal-phenolic pollutants. Appl. Clay Sci. 2018, 162, 230-238. [CrossRef]

28. Xie, Y.; Yuan, X.; Wu, Z.; Zeng, G.; Jiang, L.; Peng, X.; Li, H. Adsorption behavior and mechanism of Mg/Fe layered double hydroxide with $\mathrm{Fe}_{3} \mathrm{O}_{4}$-carbon spheres on the removal of $\mathrm{Pb}(\mathrm{II})$ and $\mathrm{Cu}(\mathrm{II})$. J. Colloid Interface Sci. 2019, 536, 440-455. [CrossRef] [PubMed]

29. Chen, M.; Zhu, R.; Lu, X.; Zhu, J.; He, H. Influences of Cation Ratio, Anion Type, and Water Content on Polytypism of Layered Double Hydroxides. Inorg. Chem. 2018, 57, 7299-7313. [CrossRef] [PubMed]

30. Kang, J.; Kang, J.; Levitskaia, T.G.; Levitskaia, T.G.; Park, S.; Park, S.; Kim, J.; Kim, J.; Varga, T.; Varga, T.; et al. Nanostructured $\mathrm{MgFe}$ and $\mathrm{CoCr}$ layered double hydroxides for removal and sequestration of iodine anions. Chem. Eng. J. 2020, $380,122408$. [CrossRef]

31. Lv, L.; Sun, P.; Gu, Z.; Du, H.; Pang, X.; Tao, X.; Xu, R.; Xu, L. Removal of chloride ion from aqueous solution by ZnAl-NO 3 layered double hydroxides as anion-exchanger. J. Hazard. Mater. 2009, 161, 1444-1449. [CrossRef] [PubMed]

32. Yang, Y.; Gao, N.; Chu, W.; Zhang, Y.; Ma, Y. Adsorption of perchlorate from aqueous solution by the calcination product of $\mathrm{Mg} /(\mathrm{Al}-\mathrm{Fe}$ ) hydrotalcite-like compounds. J. Hazard. Mater. 2012, 209-210, 318-325. [CrossRef]

33. Liu, J.; Xie, L.; Yue, X.; Xu, C.; Lu, X. Removal of fluoride and hardness by layered double hydroxides: Property and mechanism. Int. J. Environ. Sci. Technol. 2019, 17, 673-682. [CrossRef]

34. Stepanova, L.; Kobzar, E.; Leont'Eva, N.; Gulyaeva, T.; Vasilevich, A.; Babenko, A.; Serkova, A.; Salanov, A.; Belskaya, O. Study of the chemical and phase transformations in the mechanochemical synthesis of the MgAl-layered double hydroxide. J. Alloys Compd. 2022, 890, 161902. [CrossRef]

35. Daud, M.; Kamal, M.S.; Shehzad, F.; Al-Harthi, M.A. Graphene/layered double hydroxides nanocomposites: A review of recent progress in synthesis and applications. Carbon 2016, 104, 241-252. [CrossRef]

36. Sun, Y.; Zhou, J.; Cai, W.; Zhao, R.; Yuan, J. Hierarchically porous NiAl-LDH nanoparticles as highly efficient adsorbent for p-nitrophenol from water. Appl. Surf. Sci. 2015, 349, 897-903. [CrossRef]

37. Zubair, M.; Jarrah, N.; Ihsanullah, I.; Khalid, A.; Manzar, M.S.; Kazeem, T.S.; Al-Harthi, M.A. Starch-NiFe-layered double hydroxide composites: Efficient removal of methyl orange from aqueous phase. J. Mol. Liq. 2018, 249, 254-264. [CrossRef]

38. Huang, P.; Liu, J.; Wei, F.; Zhu, Y.; Wang, X.; Cao, C.; Song, W. Size-selective adsorption of anionic dyes induced by the layer space in layered double hydroxide hollow microspheres. Mater. Chem. Front. 2017, 1, 1550-1555. [CrossRef]

39. Cao, Y.; Zheng, D.; Zhang, F.; Pan, J.; Lin, C. Layered double hydroxide (LDH) for multi-functionalized corrosion protection of metals: A review. J. Mater. Sci. Technol. 2022, 102, 232-263. [CrossRef]

40. Kameda, T.; Yoshioka, T.; Mitsuhashi, T.; Uchida, M.; Okuwaki, A. The simultaneous removal of calcium and chloride ions from calcium chloride solution using magnesium-aluminum oxide. Water Res. 2003, 37, 4045-4050. [CrossRef]

41. Ren, Z.; He, J.; Zhang, C.; Duan, X. Removal of Chloride Anion by Calcined Layered Double Hydroxides. Fine Chem. 2002, 19, 339-342.

42. Lv, L.; He, J.; Wei, M.; Evans, G.; Duan, X. Uptake of chloride ion from aqueous solution by calcined layered double hydroxides: Equilibrium and kinetic studies. Water Res. 2006, 40, 735-743. [CrossRef] [PubMed]

43. Xu, J.; Song, Y.; Zhao, Y.; Jiang, L.; Mei, Y.; Chen, P. Chloride removal and corrosion inhibitions of nitrate, nitrite-intercalated Mg Al layered double hydroxides on steel in saturated calcium hydroxide solution. Appl. Clay Sci. 2018, 163, 129-136. [CrossRef]

44. Colmenares, M.C.; Mare, E. Removal of chloride ions from de wastewater using hydrotalcites as adsorbent materials. Rev. Ing. UC 2017, 24, 204-217.

45. Park, J.Y.; Lee, J.; Go, G.-M.; Jang, B.; Cho, H.-B.; Choa, Y.-H. Removal performance and mechanism of anti-eutrophication anions of phosphate by CaFe layered double hydroxides. Appl. Surf. Sci. 2021, 548, 149157. [CrossRef]

46. Feng, X.; Long, R.; Wang, L.; Liu, C.; Bai, Z.; Liu, X. A review on heavy metal ions adsorption from water by layered double hydroxide and its composites. Sep. Purif. Technol. 2022, 284, 120099. [CrossRef]

47. Jabkhiro, H.; El Hassani, K.; Chems, M.; Anouar, A. Simultaneous removal of anionic dyes onto Mg(Al)O mixed metal oxides from ternary aqueous mixture: Derivative spectrophotometry and Density Functional Theory study. Colloids Interface Sci. Commun. 2021, 45, 100549. [CrossRef]

48. Zhong, Q.; Li, H. Mg/Al layered double hydroxides prepared by microwave-assisted co-precipitation method for the removal of bromate. Huan Jing Ke Xue 2014, 35, 1566-1575. [PubMed]

49. Ye, H.; Liu, S.; Yu, D.; Zhou, X.; Qin, L.; Lai, C.; Qin, F.; Zhang, M.; Chen, W.; Chen, W.; et al. Regeneration mechanism, modification strategy, and environment application of layered double hydroxides: Insights based on memory effect. Coord. Chem. Rev. 2022, 450, 214253. [CrossRef]

50. El-Reesh, G.Y.A.; Farghali, A.A.; Taha, M.; Mahmoud, R.K. Novel synthesis of Ni/Fe layered double hydroxides using urea and glycerol and their enhanced adsorption behavior for Cr(VI) removal. Sci. Rep. 2020, 10, 587. [CrossRef] [PubMed] 
51. Sing, K.S.W. Reporting physisorption data for gas/solid systems with Special Reference to the Determination of Surface Area and Porosity. Pure Appl. Chem. 1985, 57, 603-619. [CrossRef]

52. Thommes, M.; Kaneko, K.; Neimark, A.V.; Olivier, J.P.; Rodriguez-Reinoso, F.; Rouquerol, J.; Sing, K.S.W. Physisorption of gases, with special reference to the evaluation of surface area and pore size distribution (IUPAC Technical Report). Pure Appl. Chem. 2015, 87, 1051-1069. [CrossRef]

53. Huang, Q.; Zhao, J.; Liu, M.; Chen, J.; Zhu, X.; Wu, T.; Tian, J.; Wen, Y.; Zhang, X.; Wei, Y. Preparation of polyethylene polyamine@tannic acid encapsulated MgAl-layered double hydroxide for the efficient removal of copper (II) ions from aqueous solution. J. Taiwan Inst. Chem. Eng. 2018, 82, 92-101. [CrossRef]

54. Hamidi, R.; Kazemi, P. Kinetics and mechanism of sorption of chloride ion from sodium carbonate manufacturing wastewater by Mg-Al oxide. Desalin. Water Treat. 2014, 54, 332-341. [CrossRef]

55. Miao, Y.; Peng, W.; Cao, Y.; Chang, L.; Fan, G.; Yu, F. Facile preparation of sulfhydryl modified montmorillonite nanosheets hydrogel and its enhancement for $\mathrm{Pb}(\mathrm{II})$ adsorption. Chemosphere 2021, 280, 130727. [CrossRef] [PubMed]

56. Seftel, E.M.; Ciocarlan, R.G.; Michielsen, B.; Meynen, V.; Mullens, S.; Cool, P. Insights into phosphate adsorption behavior on structurally modified ZnAl layered double hydroxides. Appl. Clay Sci. 2018, 165, 234-246. [CrossRef]

57. Chubar, N.; Samanidou, V.; Kouts, V.; Gallios, G.; Kanibolotsky, V.; Strelko, V.; Zhuravlev, I. Adsorption of fluoride, chloride, bromide, and bromate ions on a novel ion exchanger. J. Colloid Interface Sci. 2005, 291, 67-74. [CrossRef] [PubMed]

58. Jiang, X.; Yang, B.; Zhao, D.; Chen, M.; Wang, B. Process conditions of removing $\mathrm{Cl}^{-}$from solution with hydrotalcite. Ind. Water Treat. 2020, 40, 81-86.

59. Kang, G.-H.; Park, I.-K. Reconstruction and intercalating anion exchange of ZnAl-layered double hydroxide. Ceram. Int. 2022, 48, 3030-3036. [CrossRef]

60. Mahjoubi, F.Z.; Khalidi, A.; Abdennouri, M.; Barka, N. Zn-Al layered double hydroxides intercalated with carbonate, nitrate, chloride and sulphate ions: Synthesis, characterisation and dye removal properties. J. Taibah Univ. Sci. 2018, 11, 90-100. [CrossRef]

61. Yang, Z.; Fischer, H.; Cerezo, J.; Mol, J.M.C.; Polder, R. Modified hydrotalcites for improved corrosion protection of reinforcing steel in concrete-Preparation, characterization, and assessment in alkaline chloride solution. Mater. Corros. 2016, 67, 721-738. [CrossRef]

62. Tian, X.; Zhu, J.; Tang, M.; Wang, D.; Nie, Y.; Yang, L.; Dai, C.; Yang, C.; Lu, L. Surface acidity and basicity of Mg/ Al hydrotalcite for 2, 4-dichlorophenoxyacetic acid degradation with ozone: Mineralization, mechanism, and implications to practical water treatment. J. Hazard. Mater. 2021, 402, 123475. [CrossRef] [PubMed]

63. Palmer, S.; Frost, R.; Nguyen, T. Hydrotalcites and their role in coordination of anions in Bayer liquors: Anion binding in layered double hydroxides. Coord. Chem. Rev. 2009, 253, 250-267. [CrossRef]

64. Sing, K.S.W.; Williams, R.T. Physisorption hysteresis loops and the characterization of nanoporous materials. Adsorpt. Sci. Technol. 2004, 22, 773-782. [CrossRef]

65. Bansal, R.C.; Goyal, M. Activated Carbon Adsorption; CRC Press: Boca Raton, FL, USA, 2005.

66. Fan, C.; Nguyen, V.; Zeng, Y.; Phadungbut, P.; Horikawa, T.; Do, D.; Nicholson, D. Novel approach to the characterization of the pore structure and surface chemistry of porous carbon with $\mathrm{Ar}, \mathrm{N} 2, \mathrm{H}_{2} \mathrm{O}$ and $\mathrm{CH}_{3} \mathrm{OH}$ adsorption. Microporous Mesoporous Mater. 2015, 209, 79-89. [CrossRef] 